Western University Scholarship@Western

Economic Policy Research Institute. EPRI Working

Papers

Economics Working Papers Archive

2009

\title{
2009-1 The Level and Distribution of Global Household Wealth
}

James B. Davies

Susanna Sandström

Anthony Shorrocks

Edward N. Wolff

Follow this and additional works at: https://ir.lib.uwo.ca/economicsepri_wp

Part of the Economics Commons

Citation of this paper:

Davies, James B., Susanna Sandström, Anthony Shorrocks, Edward N. Wolff. "2009-1 The Level and Distribution of Global Household Wealth." Economic Policy Research Institute. EPRI Working Papers, 2009-1. London, ON: Department of Economics, University of Western Ontario (2009). 
The Level and Distribution of Global Household Wealth

by

James B. Davies, Susanna Sandström, Anthony Shorrocks and Edward N. Wolff

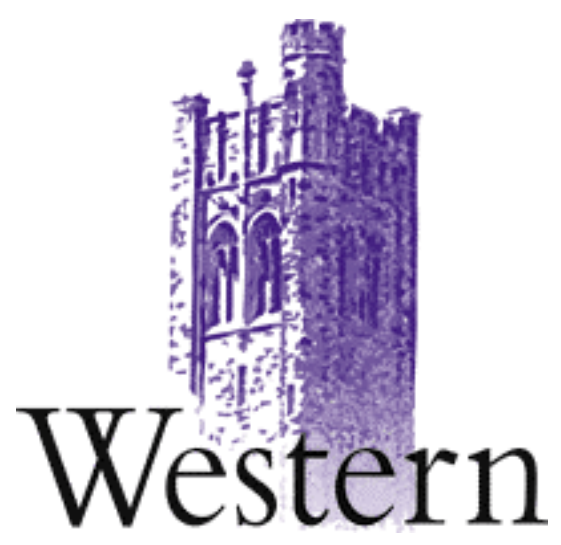

\title{
Economic Policy Research Institute EPRI Working Paper Series
}

\author{
Department of Economics \\ Department of Political Science \\ Social Science Centre \\ The University of Western Ontario \\ London, Ontario, N6A 5C2 \\ Canada
}

This working paper is available as a downloadable pdf file on our website http://economics.uwo.ca/centres/epri/ 


\title{
The Level and Distribution of Global Household Wealth
}

September 2009

\author{
James B. Davies, ${ }^{1}$ Susanna Sandström, ${ }^{2}$ Anthony Shorrocks, ${ }^{2}$ and Edward N. Wolff $^{3}$ \\ ${ }^{1}$ Economics Dept, University of Western Ontario; ${ }^{2}$ UNU-WIDER, Helsinki; \\ ${ }^{3}$ Economics Dept, New York University.
}

\begin{abstract}
We estimate the level and distribution of global household wealth. The levels of assets and debts for 39 countries are measured using household balance sheet and survey data centred on the year 2000. The determinants of mean financial assets, non-financial assets, and liabilities are studied empirically, and the results used to estimate average wealth holdings for countries lacking direct evidence. Data on the pattern of household distribution of wealth are assembled for 20 countries, which together account for 59 per cent of the global population and 75 per cent of global wealth. The observed relation between wealth and income distribution in these 20 countries allows estimates of wealth inequality to be produced for many other nations. Combining the figures for individual countries reveals that net worth averaged US\$44,024 per adult in PPP terms across the globe. Wealth of US\$8,635 was needed to be in the top half of the global distribution, and US\$518,364 to be in the top one per cent. The top 10 per cent owned 71 per cent of world wealth, and the Gini coefficient for the global distribution of wealth is estimated to be 0.802 , indicating greater inequality than that observed in the global distribution of consumption or income.
\end{abstract}

Keywords: wealth, net worth, personal assets, inequality, households, balance sheets, portfolios

JEL classification: D31, E01, E21, O10

Acknowledgements: We thank participants at the May 2006 UNU-WIDER project meeting on Personal Assets from a Global Perspective, and the August 2006 International Association for Research in Income and Wealth 29th General Conference in Joensuu, Finland, for their valuable comments and suggestions. Special thanks are due to Tony Atkinson, Brian Bucks, Markus Jäntti, and Branko Milanovic. Responsibility for errors and omissions is our own. 
The world distribution of income has recently been the subject of much attention. Available evidence suggests that global income inequality is high and not trending down over time (Bourguignon and Morrison 2002; Milanovic 2002, 2005). Indeed, in some regions both poverty and income inequality appear to be on the increase. Given these findings, interest naturally turns to global disparities in other dimensions of economic status, resources or wellbeing, of which one of the most important is household wealth. In recent years the number of countries with good wealth data has increased and it is now possible to try to estimate the global distribution of household wealth, which is the goal of this paper.

The core data for this exercise are provided by national wealth distribution data that are available for 20 countries. These countries include the largest and richest countries in the world and together account for 59\% of the world's population and, we estimate, $75 \%$ of its wealth. While it is interesting to look at the distribution of wealth just for these countries, and we do provide those results, our main focus is on an estimate of the full global distribution of wealth. This requires imputation of both wealth levels and distribution to the countries with missing data. Much of the paper is occupied with the development and application of those imputations. We find that the global distribution of wealth so estimated is quite close to that for the 20 core countries-yielding a Gini coefficient of .802 for example in comparison with .796 for the core group.

Estimating the global distribution of wealth involves two stages. First, the average wealth level in each country is established. This is done by using national household balance sheet (HBS) data, and survey data where there are no HBS numbers, and then extending the wealth figures to nations with neither kind of data using regression based imputations. The second stage requires the shape of the distribution to be computed for each country. Again there are countries with direct data (the 20 referred to above), and others for which the pattern must be estimated using the best available proxies. Our ultimate aim is to produce household wealth distribution estimates on a per adult basis for the year 20001. This paper focuses almost

\footnotetext{
1 Although HBS data are available annually in many countries, wealth distribution data typically come from surveys that are conducted at intervals of three or more years and whose results are available only with a significant lag. The year 2000 provides us with a reasonably recent date and good data availability.
} 
exclusively on figures based on purchasing power parity (PPP) exchange rates. Davies et al (2008) reports results from earlier work using official exchange rates.2.

This paper establishes, first, that there are very large inter-country differences in the level of household wealth. The USA is the richest country in aggregate terms, with wealth estimated at PPP\$ 201,319 per adult in the year 2000. At the opposite extreme among countries with wealth data, India has per adult wealth of \$12,201 in PPP terms. Other countries show a wide range of values. Even among high income OECD countries the figures range from \$70,461 for Finland, and \$79,585 for New Zealand, to \$172,461 for the UK. We also find that the wealth to income ratio rises with income or wealth, meaning that in poor countries the relative shortfall of wealth is greater than that of income. This is a noteworthy result since the risks, capital market imperfections, and lack of social safety nets that people face in poor countries mean that personal assets seem to be most lacking where they are most needed.

International differences in the composition of wealth are also examined. Some regularities are evident, but also country-specific differences — such as the strong preference for liquid savings in Japan and some other countries. Real assets, particularly land and farm assets, are more important in less developed countries. This reflects not only the greater importance of agriculture, but also an immature financial sector (that is currently being addressed in some of the rapidly growing developing countries) and other factors such as inflation risk. Among rich nations, there is significant variation in the importance of financial assets and share-holding.

Concentration of wealth within countries is high. Gini coefficients for wealth typically lie in the range of about 0.6-0.8. In contrast, most Gini coefficients for disposable income fall in the range $0.3-0.5$. The mid value for the share of the top 10 per cent of wealth-holders in our core country-level data is 51 per cent, again much higher than is common for income.

The paper finds that global wealth-holding is highly concentrated, much higher than in the case of income. The share of the top 10 per cent of adults in 2000 is estimated to be 70.7 per cent and the Gini coefficient to be 0.802 . The share of the bottom half is just 3.7 per cent. Although inter-country differences are greater than in the case of income, we find that intracountry inequality is so much larger in the case of wealth that it accounts for a larger share of global inequality than it does for income, according to the Gini coefficient. Thus the principal

\footnotetext{
2 The present paper differs from Davies et al (2008) not only in using PPP exchange rates, but in its empirical framework for the estimation and imputation of wealth levels by country. This framework is set out in Section 3 of the present paper. The estimate of global wealth distribution provided here supersedes that in our earlier work.
} 
reason for the high global inequality of wealth may be the long-recognized high inequality of wealth within countries.

The remainder of the paper is organized as follows. The next section describes what can be learned about household wealth levels and composition across countries using household balance sheet and survey data. Section 3 presents our results on the determinants of wealth levels, and assigns household wealth figures to the 'missing countries'. Section 4 reviews the available evidence on the pattern of wealth distribution, and then performs imputations for other countries. In Section 5 the data on levels and distributions are combined to construct the global distribution of household wealth. Conclusions are drawn in Section 6.

\section{Wealth levels and composition in countries with data}

This section assembles data on wealth levels and composition for as many countries as possible. These data are of independent interest, but are also used in the next section to impute per capita wealth to countries that lack wealth data. The exercise begins by taking inventories of household balance sheet (HBS) and sample survey estimates of household wealth levels and composition. 3

\subsection{Household balance sheet (HBS) data}

As indicated in Table 1, 'complete' financial and non-financial balance sheet data are available for 19 countries. These are all high-income countries, except for the Czech Republic, Poland, and South Africa, which are classed as upper middle-income by the World Bank. 4 We term the data complete if they adequately cover each of financial assets, liabilities and non-financial assets. 5 Sixteen other countries have financial balance sheets, but no

\footnotetext{
3 The sources and methods for balance sheet and survey data are described in Appendices I and II.

4 The World Bank (WB) classification is used throughout the paper except that Brazil, Russia, and South Africa were moved from the lower middle-income category to higher middle-income, and Equatorial Guinea from low to lower middle-income. These changes were prompted by the fact that the WB classifications seems anomalous compared to the Penn World Table GDP data that was used for the year 2000.

5 There are some national differences in asset coverage, particularly for non-financial assets. The figures for each country with a complete balance sheet here include both owner-occupied housing and consumer durables. There is some variation in coverage of other real estate. See Appendices I and II for more detail.
} 
information on real assets. This group is less biased towards the rich world since it contains six upper middle income countries and three lower middle income countries.

Regional coverage in HBS data is not representative of the world as a whole. Such data tend to be produced at a relatively late stage of development. Europe and North America, and the OECD in general, are well covered, but low-income and transition countries are not.6 In geographic terms this means that coverage is sparse in Africa, Asia, Latin America, and the Caribbean. Fortunately for this study, these gaps are offset to an important extent by the availability of survey evidence for the largest developing countries, China, India and Indonesia. Also note that while there are no HBS data for Russia, complete HBS data are available for two European transition countries and financial data for eight others.

The asset composition of household balance sheets in different countries, shown in Table 2, reflects influences such as market structure, regulation and cultural preferences (IMF 2005). For most countries, non-financial assets account for between 40 and 60 per cent of total assets, with higher shares in the Czech Republic, New Zealand, Poland, and Spain. Housing assets constitute a considerable share of non-financial assets. These assets include both owner-occupied housing and rental property. ${ }^{7}$ In a number of countries, for example Italy, Spain and the UK, the large increase in real estate prices in the late 1990s helps to explain the high share of housing. The high share of financial assets makes South Africa stand out. 8 The USA is also an outlier in the share of financial assets, which is related to the strength of its financial markets and importance of private pensions but also to the strong stock market performance in the period leading up to the year 2000.

The composition of financial assets can be examined not only for the 19 countries with complete balance sheets but also the 16 countries with only financial balance sheets. Striking differences across countries are evident when financial assets are disaggregated. Liquid assets

6 Goldsmith (1985) prepared ‘planetary’ balance sheets for 1950 and 1978 and found similar difficulties in obtaining representative coverage. He was able to include 15 developed market economies, two developing countries (India and Mexico), and the Soviet Union. This produces a total of 18 countries, one less than the number of countries for which we have complete HBS data for the year 2000.

7 Only housing owned directly by households or unincorporated businesses is included here. Real estate may also be owned by other sectors, including the corporate sector.

8 One would expect real assets to be important in a developing country, but the well developed financial markets in South Africa, combined with negative rates of return on investment in fixed property and high mortgage interest rates in the 1990s, resulted in an unusually low share of non-financial assets in the year 2000 (see Aron et al. 2008). 
are a large part of the total in Japan and in most of the European transition countries. The preference for liquidity in Japan has a long history, but also reflects the poor performance of real estate and shares in the 1990s (Babeau and Sbano 2003). The share of other financial assets is particularly high in Australia, Austria, the Netherlands, South Africa, and the UK, which may be partly due to the importance of pension fund claims in these countries. Italy has a very low share of liabilities, a well-known phenomenon that is confirmed by survey data (see below). Poland and the Czech Republic also have low debt ratios, reflecting the underdevelopment of mortgage and consumer credit in these transition countries.

\subsection{Survey data}

In order to check the HBS data and to expand our sample, especially to non-OECD countries, household wealth survey data were also consulted. ${ }^{9}$ Country coverage is broader than in HBS data (see Table 3). Most importantly, wealth surveys are available for the three most populous developing/emerging market countries: China, India and Indonesia. These three countries, together with Mexico in the case of non-financial assets, are used in regressions in Section 3 that provide the basis for wealth level imputations for our 'missing countries'.

Like all household surveys, those of wealth are affected by sampling and non-sampling errors. The high skewness of wealth distributions makes sampling error important. Non-sampling error is also a problem due to differential unit response - wealthier households are less likely to respond - and under-reporting, especially of financial assets. Both sampling and nonsampling error lead to difficulties in obtaining an accurate picture of the upper tail of the wealth distribution (see Davies and Shorrocks 2000: 605-76, 2005). In order to offset these effects an increasing number of surveys over-sample wealthier households. This is the practice in the US Survey of Consumer Finances for example as well as in surveys in Canada, Germany and Spain.10 Over-sampling at the upper end has not been adopted in the major

9 In the next section, where we must provide a single estimate for the wealth level in each country, we use HBS data, where available, in preference to survey data. While HBS data are of course also subject to error, a country's wealth survey results can be, and normally are, used as an input in creating HBS estimates. Since the HBS estimates benefit from additional inputs of information and data from other sources, they should, in principle, dominate wealth survey estimates. The Survey of Consumer Finance (SCF) in the USA is of such high quality, however, that it is not clear whether HBS or survey data should be preferred (see, for example, Bertaut and Starr-McCluer 2002: 181-218). Fortunately for our purposes, HBS and SCF estimates of total household wealth in the USA in 2000 are very similar (see below). Our results would differ little if the SCF had been used to establish the USA wealth level.

10 The SCF design explicitly excludes people in the Forbes 400 list of the wealthiest Americans, which again helps to reduce the effects of sampling error; see Kennickell (2006: 19-88). 
developing countries represented here, but these countries have much higher response rates than are seen in the developed countries, and China and India have large samples, helping to reduce sampling error. 11

Aside from the USA - whose sophisticated Survey of Consumer Finance succeeds in capturing most household wealth - surveys usually yield lower totals for financial assets compared with HBS data, principally due to the lower response rate of wealthy households and under-reporting by those who do respond.12 (See Appendix III for a comparison of wealth estimates from household balance sheets vs. surveys.) In contrast, survey totals for the most important non-financial asset, owner-occupied housing, are more accurate. (See Davies and Shorrocks, 2000, p. 630.)

Table 3 reports asset composition in the survey data. It is clear that non-financial assets bulk larger in surveys than in HBS data, reflecting both the relative accuracy of housing values in survey data and the importance of non-sampling error in the case of financial assets. The table also highlights the relative importance of reported financial and non-financial assets in developed and developing countries. The two low-income countries in our sample, India and Indonesia, stand out as having particularly high shares of non-financial wealth. 13 This reflects both the importance of land and agricultural assets and the lack of financial development. In India, the only low or middle income country for which the composition of financial assets is reported in Table 3, most of the financial assets owned by households are liquid. In Table 3, China does not stand out as having a high share of non-financial assets. One reason is that the value of housing is reported net of mortgage debt in China. Another is that there is no private

11 See Deaton (1995) on the high response rates to surveys in developing countries in general. As reported in Davies and Shorrocks (2005), response rates in the 1991-92 Indian AIDIS were 95.7 per cent and 94.6 per cent in rural and urban areas respectively. The sample size in the 2002 survey in China was 16,035, and in the 1991-92 survey in India it was 57,031 .

12 Statistical organizations fight these forms of non-sampling error through their survey technique and questionnaire design. Once the results are in, it is also possible to try to correct for these errors. Particularly ambitious efforts have been made in the Italian SHIW survey. Brandolini et al (2004) uses records of the number of contacts needed to win a response to estimate the differential response relationship, which allows reweighting. He also uses results of a validation study comparing survey responses and institutional records to correct for misreporting of selected financial assets. Finally, this study also imputes non-reported dwellings owned by respondents (aside from their principal dwelling).

13 This echoes the findings of Goldsmith (1985) who reported that India and Mexico had an average of 65 per cent of national assets in tangible form in 1978, compared to 51 per cent for 14 developed market economies. 
ownership of urban land. And of course there has been rapid accumulation of financial assets by Chinese households in recent years. The ratio of liabilities to total assets is particularly low in India and Indonesia (for China only non-housing liabilities are reported). Again poorly developed financial markets help to explain this phenomenon. Italy also stands out as having a very low share of liabilities. This low share echoes the finding in HBS data, and likely reflects the relative lack of mortgage loans in Italy compared to other OECD countries.

Combining the balance sheet and survey data, it is evident that there are major international differences in asset composition. Real property, particularly land and farm assets, are more important in less developed countries, while financial assets are more important in rich countries. There are also major international differences in the types of financial assets owned. Savings accounts are favoured in transition economies and some rich Asian countries, while share-holdings and other types of financial assets are more evident in rich Western countries. Debt is also less important in developing and transition countries than in the more developed countries (with the notable exception of Italy).

\subsection{Wealth levels from household balance sheet and survey data}

When wealth levels are compared across countries, one of the first issues to be confronted is the appropriate rate of exchange between currencies. In comparisons of consumption or income there is widespread agreement that international price differences should be taken into account via the use of PPP exchange rates.14 This procedure seems appropriate for wealth holdings also if the focus of attention is, say, the bottom 95 per cent of wealth-holders, for whom domestic prices are the main determinant of the real value of their assets. However, a large share of wealth is held by households in the top few percentiles of the distribution. People in this category, and their financial assets, tend to be internationally mobile, making exchange rates more relevant for international wealth comparisons among the rich and superrich.

This paper follows the convention of using PPP exchange rates to compare countries; unless otherwise stated, all wealth figures are expressed in PPP US dollars for the year 2000.

14 There is, however, some disagreement about the type of PPP exchange rates that should be used. We follow common practice and use the Penn World Table PPP rates, which are based on the Geary-Khamis method. This method has many practical advantages, including desirable adding-up properties. The leading competitor is the method proposed by Elteto, Koves and Szulc (EKS), which has been used by the OECD and Eurostat to compare income across their member countries. See Neary (2004) for a discussion of the theoretical basis for the GearyKhamis method. 
Selected comparable figures on an exchange rate basis are presented in footnotes and appendices. They are also discussed in detail in Davies et al. (2008) which places more emphasis on the upper tail of the distribution.

Table 4 summarizes information on the per capita wealth and income of countries with complete household balance sheet or wealth survey data (data for individual countries are given in Appendix III). Of the 19 countries that have complete HBS data, the USA ranks first with per capita wealth of $\$ 143,727$ in 2000 , followed by the UK at $\$ 128,959$, Japan at $\$ 124,858$, the Netherlands at $\$ 121,165$, Italy at $\$ 120,897$, and then Singapore at $\$ 113,631$. South Africa is in last place, at $\$ 16,266$, preceded by Poland at $\$ 24,654$, and the Czech Republic at \$32,431. The overall range is rather large, with per capita wealth in the USA 8.8 times as great as that of South Africa. The (unweighted) coefficient of variation (CV) among the 19 countries is 0.440 .

The next column shows GDP per capita. In the group of 19 countries with HBS data, the USA again ranks first, at $\$ 35,619$, and South Africa last, at $\$ 8,017$. However, the range is much smaller than for net worth per capita. The ratio of highest to lowest GDP per capita is only 4.4, and the coefficient of variation (again among the 19 countries) is 0.301 . These results are a first indication, which our full results confirm, that wealth is more unequally distributed across countries than is income. Note that while it is well-known that wealth is more unequal than income within countries, that common observation does not imply anything about differences across countries. Column four shows personal disposable income per capita for the same group of countries. The USA again ranks first, at $\$ 25,480$, South Africa is again last, at $\$ 4,691$, and the ratio of highest to lowest is 5.4 , slightly higher than for GDP per capita. The coefficient of variation is 0.331 , again slightly higher than that of GDP per capita. The fifth column shows real consumption per capita, whose dispersion is intermediate between that of GDP and disposable income. All in all, the per capita variation of net worth is much greater than that of GDP, disposable income or consumption.

Differences across countries are even more pronounced in survey data due to the inclusion of China, India, and Indonesia. Of the 13 countries with the pertinent data, the USA again ranks first in net worth per capita, at $\$ 143,857$, followed by Australia at $\$ 101,597$, and Japan at $\$ 91,856$. In this group, India and Indonesia occupy the bottom two positions, at $\$ 6,513$ and $\$ 7,973$, respectively. China appears to be about twice as wealthy as India, having per capita net worth of $\$ 11,267$. Note that the PPP adjustment has a proportionately greater impact on the figures for developing countries. Using official exchange rates, all three countries have much lower per capita wealth: India is at $\$ 1,112$, Indonesia at $\$ 1,440$, and China at $\$ 2,613$. Hence inequality in wealth between countries is greater using official exchange rates, as reflected in the $\mathrm{CV}$ of 0.612 shown in the table versus 0.440 on a PPP basis. In the survey 
data, as in the HBS data, the range in per capita wealth is much larger than that of per capita GDP, disposable income, or consumption. The ratio of highest to lowest is 22 for wealth per capita, 13 for both GDP and disposable income, and 17 for consumption. The coefficients of variation for the income and consumption variables are again smaller than for wealth, and higher using official exchange rates than PPP rates.

How large are the differences in the picture that one gets from HBS vs. survey data? There are 10 countries that have both types of data. For these countries the (simple) average of mean per capita PPP wealth is $\$ 98,364$ in HBS data and $\$ 74,579$ in survey data, a difference of 24 per cent. (The difference is 25 per cent using official exchange rates.) The correlation between HBS and survey means is just 0.62 on the PPP basis, although it rises to 0.83 , using official exchange rates. The difference in means and the imperfect correlation are, we believe, largely a result of the uneven quality of survey evidence across countries. Given the latter, it seems clear that an approach in which one simply aggregated national survey data to estimate the world distribution of wealth would be inadequate. Since more consistent information is available, in the form of HBS data, in establishing wealth levels by country the latter should be used as far as possible. That is the approach followed in estimating the global distribution of wealth later in this paper.

\section{$3 \quad$ Estimates of wealth levels and composition for all countries}

The next step is to generate per capita wealth values for the remaining countries of the world. As explained below, regressions run on the 39 countries with HBS or survey data enable part or all of wealth to be estimated for many countries. This yields a total of 148 countries with observed or estimated wealth, covering 95.2 per cent of the world's population in 2000 . Separate imputations are made for the 81 countries that make up the remaining $4.8 \%$, as explained later in this section.

The purpose of the empirical exercise reported in this section is to predict wealth levels in countries where wealth data are missing. This imposes certain limitations. Most importantly, the independent variables in our regressions need to be available not only for the countries with wealth data, but also for most of those without such data-otherwise we would not be able to impute wealth to the "missing countries". Fortunately, this limitation does not prevent us from estimating a sensible empirical model of personal wealth levels across countries. 


\subsection{Empirical specification}

The basic life-cycle model (LCM) under certainty and perfect capital markets, and without government, provides a useful starting point for our empirical model.15 Suppose that intertemporal preferences, and the ages of starting work and retiring were the same everywhere, but that length of life, $L$, varied internationally. Assume also that the real interest rate $r$ was zero and that growth rates of both labour income and population, $g$ and $p$ respectively, were constant but differed across countries. For simplicity assume that workers are all employed full-time and have exogenous earnings. Then, mean wealth would be determined by $g, p, L$, and mean earnings, $y$. In steady-state we would have:

$$
W=f(g, p, L) y
$$

(See Brumberg and Modigliani, 1980, or Modigliani 1988.) A strong prediction of the LCM is that $L$ will have a positive effect here. The growth rates $g$ and $p$ have a mild negative effect in the simple LCM.16 The model can be extended to a world with government by redefining $r$ and $y$ as net of taxes and transfers.

While (1) takes us some way, it does not provide the entire basis for an empirical specification. Ideally one should take into account international differences in the age of retirement, for example. This is unfortunately impractical since the data are not available on a consistent basis for enough countries. But what of the role of the interest rate and that of public pensions? The impact of $r$ in the LCM is complex and ambiguous. Also, empirical work finds conflicting, and often insignificant, impacts (Modigliani, 1988). Since we also do not have good data on $r$ for a large set of countries we do not attempt to include it in our

15 As far as we know, there have been no previous regression-based studies of the determinants of international wealth differences. Part of the original motivation for the LCM was to explain international differences in saving and wealth (see e.g. Deaton 2005). Results for international differences in saving have been mixed, but the life-cycle framework has proven useful in studying saving at the micro level (see Browning and Crossley, 2001) and wealth distribution in macroeconomics (see Cagetti and De Nardi, 2008). The LCM is fruitful in the present application in part because one of its central predictions, that wealth should increase with longevity (assuming this translates into longer retirements), holds here statistically.

16 Steady-state saving will increase with both $g$ and $p$, but the wealth to income ratio (W/y) tends to decline mildly with $g$ and $p$. The reason is that there is, for the most part, a positive relationship between wealth and age in the LCM (the working period of rising wealth is longer than retirement, and also early retirees have relatively high wealth). Higher $p$ increases the relative number of young people, reducing $W / y$. Higher $g$ increases both the relative wealth and labour income of the young, but the effect of this on average income tends to be stronger than that on mean wealth, so again $W / y$ tends to fall. 
regressions. Pensions are a different matter. In the simplest version of the LCM, where consumption is constant over the lifetime and $r=g=p=0, y$ can be replaced in (1) by $y-b$, where $y$ is net of pension contributions and $b$ is the (constant) pension received in retirement. Public pensions thus have a direct negative effect on private wealth. However, in more complex versions of the LCM, and especially if impacts on age of retirement are taken into account, the effect of public pensions becomes ambiguous. (See e.g. Gale, 1998.) Nevertheless, although the evidence is mixed, several good empirical studies suggest a significant effect of pensions on wealth within a country. 17 We tested for a similar effect internationally in the work reported below, but no significant impact was found.

It must also be recognized that the steady-state assumption is a poor approximation in some cases, for example transition countries. Further, capital and other markets are not perfect. Access to financial institutions and products varies across countries, as do housing market institutions and the ease of mortgage finance. While (1) may provide a preliminary basis for our work, these additional effects also need to be taken into account. We do this by introducing a dummy variable for transition countries and introducing variables that may reflect relevant capital market differences, as discussed below.

One approach here would be to simply regress $\log W$ on the "LCM variables" shown on the right-hand side of (1), with some allowance for transition countries and capital market imperfections. We can do that for the 23 countries that have data on both financial and real wealth. However, there is one country (Mexico) with data on real assets alone and 15 countries with good data on financial assets and liabilities. It would be unfortunate to exclude these countries, especially since they include a higher proportion of transition and middleincome countries. This raises the possibility of running separate regressions for real vs. financial wealth. How does that square with the framework we have been developing?

The simple LCM is silent on the division of wealth between different kinds of assets. ${ }^{18} \mathrm{~A}$ naïve hypothesis would be that the various assets would be held in the same proportion in different countries. In this world one could run separate regressions for different asset groups, but there would be no benefit since each regression would estimate the same coefficients except for scale. And there could be a cost if measurement error in the dependent variable

17 See Gale (1998) for a summary, as well as Bottazzi et al. (2006) and Gale et al. (2007) on more recent work.

18 If current income is low people may be net borrowers in the LCM, which implies holding some debt. This is the only prediction from the LCM regarding wealth composition, and even this prediction does not say much, since those with negative net worth could have assets as well as debts, so that their net borrowing may differ from their debt. 
declines in importance with aggregation, as seems likely here. We ran separate regressions on real assets, financial assets, and liabilities using the same variables and found that the hypothesis of a common structure was, in fact, strongly rejected. Further, as we see below, there are grounds for introducing non-common variables in these regressions and they perform well empirically. In this situation, as shown by Kennan (1989), there would be aggregation bias if a single equation were run for $W$. And since this cannot be done for the full sample of 39 countries in any case, our preferred approach is to run three separate regressions.

To give a behavioural basis to the three equations approach one must move beyond the simple LCM and think about differences in asset characteristics, including risk and return. There is a literature on optimal portfolio selection in a life-cycle context. It finds that the intuitive idea that people should hold a less risky portfolio as they age is correct, at least beyond the middle working years, under plausible assumptions. (See Benzoni et al., 2007, and Gomes et al., 2008.) Here that might suggest, e.g., that countries with higher population growth should have a higher ratio of financial to non-financial assets, assuming that financial assets are riskier.19 The amount that people will save depends on the menu of risks and returns on different assets. One cannot generally decompose savings decisions into an "LCM decision" of how much to save and a portfolio allocation decision. This indicates that in a more general version of the LCM risk elements would affect mean wealth.

One of the most important personal assets, housing, is held for consumption as well as investment purposes. With perfect markets this need not affect mean wealth. Households can rent, or borrow freely to keep housing equity in line with life-cycle saving plans. However, in the real-world mortgage finance is not so flexible, and tax or other institutions may favour owner-occupation. In this context, impacts on mean wealth can come from the housing market. For example, if the consumption demand for housing is inelastic, mean wealth may tend to be higher where housing is more expensive.

Because errors in our three equations are likely to be correlated, we use the seemingly unrelated regressions (SUR) technique due to Zellner (1962) (see Greene 1993: 486-99). This involves stacking equations and estimating via generalized least squares. While OLS estimates are consistent, SUR provides greater efficiency, with the gain in efficiency increasing with the correlation of the errors across the equations, and decreasing with the

19 Benzoni et al. (2007) emphasize that the optimal share of risky assets is hump-shaped over the life-cycle when cointegration of labor and stock returns is recognized. Whether a fast growing country would have a higher overall ratio of risky assets in their model therefore depends on the shape and peak age of this hump. 
correlation of the regressors used in the different equations. Since we have an equal number of observations for financial assets and liabilities, but fewer observations for non-financial assets, and since we believe errors are more likely to be correlated between financial assets and liabilities than between the latter variables and non-financial assets, we have applied SUR here only for financial assets and liabilities.

\subsection{Wealth Regressions}

Table 5 shows our main regression results. For comparison we show single-equation regressions for $\log W$ as well as our three equations for asset subgroups. In each case we show the preliminary specification (a) and the final specification (b). The two specifications mainly differ in that variables that were insignificant in (a) are not used in (b). However, in a few cases variables that were insignificant in (a) become significant when other insignificant variables are omitted, and are retained in the (b) regressions.

Our first four regressors try to capture the four LCM variables $y, L, g$ and $p .20$ We initially used personal disposable income per capita for $y$, and it performs well. However, this variable is not available for many of our "missing countries", and so cannot be used to perform the intended imputations. In Table 5 we therefore report results using real per capita consumption 21 to play the role of $y-$ it is highly correlated with $y$ in-sample and its use has only a small impact on the estimated coefficients. This variable is significant at the $1 \%$ level in all our equations. Interestingly, while the estimated coefficients are insignificantly different from unity in most cases, for non-financial assets the coefficient is significantly less than 1. The coefficient is very close to 1 for financial assets, and equals 1.199 for liabilities. These aspects are important, since in our imputations financial assets will increase roughly in proportion to income, but non-financial assets will rise less, and liabilities slightly more than in proportion to income.

20 Various specifications were tried for public pensions, including the replacement of $y$ by $y-b$ in line with the simple LCM. The $y-b$ variable performed distinctly worse than $y$ alone. When pension variables were introduced independently they were insignificant in all our equations. (This may be partly explained by the fact that the variable was not available for many of the low and middle income countries in our sample.) Given these findings, we do not report regressions including a public pension variable here.

21 Real consumption per capita is from Penn World Tables 6.1 and is based on National Accounts (NA) data. NA consumption data measure most forms of consumption on the basis of current purchases. An important exception is housing consumption, which is measured by the value of housing services consumed. This means that the item includes rents or, in case of home owners, imputed rents. See Commission of the European Communities et al., Ch. IX, section D. 
For $L$ we use life expectancy in 1980, attempting to capture conditions when the average adult of 2000 was in the middle of working life and forming expectations about his/her likely length of life and retirement.22 This variable is highly significant for total wealth and for nonfinancial assets. It is also significant at the $5 \%$ level for both financial assets and liabilities.23

The growth rates $g$ and $p$ are each significant in just one of the (b) specification regressions in Table 5. Per capita GDP growth is retained in the financial assets regression, but while population growth is significant for total wealth, it is not retained in the (b) specification of any of the three asset-specific equations. This general lack of significance may reflect the fact that, as mentioned earlier, the impact of these variables on $W / y$ is expected to be mild on the basis of the LCM.

Turning to the additional variables, we used the (log of) population density as a proxy for house prices, expecting a positive impact on non-financial assets, which is indeed found. (The variable is also highly significant for total wealth.) Significant positive effects are found for the market capitalization rate in the financial assets regression, and domestic credits available to the private sector in the liabilities regression (both again in logs). These effects are consistent with better functioning of capital markets leading to their greater use. The urbanization (\% urban) and phone participation (\% with phones) variables were included as they could affect ease of access to financial products. These variables were expected to have positive effects on both financial assets and liabilities. This expectation was correct for liabilities, but not for financial assets.

Finally, we have two dummies - one for cases where the data source is a survey rather than HBS data, and the other for transition countries. The survey dummy is only significant in the financial assets regression, but there it is highly significant and also has a large negative coefficient. This means that if the data source is a survey, mean financial assets will tend to be much lower than if the data are from national balance sheets. We use this result to adjust upwards the estimates of mean financial assets in both the wealth levels and distributional calculations reported below for China, India and Indonesia. The transition dummy has a highly significant, but smaller, negative impact on non-financial wealth and total wealth. In contrast to the survey dummy, we believe the transition dummy is telling us something about

22 Using 1980 rather than a more recent year for $L$ also avoids the distortion in this variable caused in recent years by the AIDS epidemic, particularly in sub-Saharan African countries.

23 Note the negative sign for liabilities, suggesting that higher mean wealth occurs partly through greater assets and partly through lower debts. 
the real-world - that the values of non-financial assets in transition countries are depressed, perhaps due to incomplete housing markets and under-developed housing finance.

\subsection{Estimated wealth levels}

Table 6 summarizes the wealth levels obtained for the world and its regions. HBS data are used where available (see Table 1); corrected survey data are used for China, India and Indonesia. Financial assets and liabilities are imputed for 110 countries, and non-financial assets for 125 countries, using the regressions described in the previous section. For the 81 countries that lack any data, the mean per capita wealth of the appropriate continental region (6 categories) and income class (4 categories) 24 were assigned. This imputation is admittedly crude, but better than simply disregarding the excluded countries. It allows us, in the end, to assign wealth levels to 229 countries.

Table 6 provides both per capita and per adult numbers, each weighted by their respective population weight. 25 For the world as whole in 2000, net worth was estimated to be $\$ 26,738$ per capita and \$44,024 per adult. North America accounted for 27 per cent of world household wealth, much more than its 5 per cent share of world population and greater than its 24 per cent share of world GDP. The 'rich Asia-Pacific' group and Europe show a similar pattern, with wealth shares much greater than their population shares and larger than their shares of world GDP.26 Given these results, it is not surprising to see that between-country inequality, as shown by the Gini coefficient, is higher for wealth than GDP (0.583 vs. 0.503 respectively on a per capita basis). Note also that between-country wealth inequality is lower using the per adult basis (which gives a Gini coefficient of 0.533), reflecting the fact that the difference between wealth per capita and per adult is greater in poor countries, which have a higher proportion of children in their populations.

\footnotetext{
24 Our regional calculations treat China and India separately due to the size of their populations. In the regional breakdowns it was also convenient to distinguish the high income subset of countries in the Asia-Pacific region (a list which includes Japan, Taiwan, South Korea, Australia, New Zealand, and several Middle Eastern states) from the remaining (mainly low-income) nations.

25 While per capita magnitudes are more familiar, we argue in the next section that it is best to analyze the world wealth distribution among adults rather than all individuals. It is therefore helpful to begin looking at per adult, as well as per capita, figures at this point.

26 Note that the disproportion between wealth and population shares, although large, is less for Europe than the other high wealth regions. This reflects in part the inclusion of the lower wealth countries of Eastern Europe.
} 
The rich Asia-Pacific group includes Hong Kong, which has the highest mean wealth in the world on per capita basis and the second highest on a per adult basis according to our estimates - \$175,191 per capita and \$228,675 per adult, or 5.2 times the world average per adult (see Appendix VI as well as Table 6). This group also includes Japan and Singapore, both at 3.6 times the world average per adult. Europe contains both very high wealth countries, such as Luxembourg (the first place country per adult, as Hong Kong also with wealth 5.7 times the world average), the UK (3.9 times the world average), and the Netherlands and Italy (3.6 and 3.4 times the world average respectively), as well as low wealth countries such as Moldova (29 per cent of the world average), the Ukraine (43 per cent), and Albania (47 per cent).

Lower down the scale, China and India collectively accounted for 37 per cent of world population in the year 2000, but only 16 per cent of world GDP and 14 per cent of the global wealth. China's net worth per adult was \$19,056 (43 per cent of the world average) and India's was \$12,021 (27 per cent). Latin American and the Caribbean had 9 per cent of the world's population and GDP, but 6 per cent of world wealth. Among this group, the wealthiest countries include Barbados (3.4 times the world average per adult), Puerto Rico (2.8 times), and Trinidad and Tobago (2.1 times). The less affluent countries in this group include Haiti (18 per cent of the world average), Bolivia (19 per cent) and Honduras (27 per cent).

Africa and 'other Asia-Pacific' countries together accounted for 33 per cent of the world population but only 14 per cent of world GDP and 9 per cent of global wealth. Almost all countries in the other Asia-Pacific group have net worth per adult below the world average, except for Lebanon positioning itself just above the mean. Yemen (5 per cent) and Cambodia (10 per cent) are the least wealthy countries in this group. With the notable exception of Mauritius and the Seychelles (2.4 and 1.1 times the world average per adult), the African nations are all below average in per capita wealth and include South Africa (66 per cent of the world average), Zimbabwe (39 per cent), Kenya (22 per cent), Uganda (13 per cent), Tanzania (5 per cent), and Nigeria (3 per cent). 


\section{$4 \quad$ Wealth distribution within countries}

In order to estimate the global distribution of wealth we need estimates of the distribution within countries. We start by assembling estimates for countries with hard data. We then perform imputations for the remaining countries. The resulting estimates are intended mainly as an input into our global calculations but also have some independent interest, as we bring out in the discussion. 27

As indicated in Table 7, information on the distribution of wealth across households or individuals can be assembled for 20 countries. One set of figures was selected for each nation, with a preference for the year 2000, ceteris paribus. In most countries there is only one suitable data source. Where there was a choice we assessed sources in terms of how comprehensive their population and asset coverage were, the unit used (adults being preferred to families or households), and how well they dealt with sampling error, particularly as it affects the upper tail.28 To assist comparability across countries, a common distribution template was adopted, consisting of the decile shares reported in the form of cumulated quantile shares (i.e. Lorenz curve ordinates) plus the shares of the top 10 per cent, 5 per cent, 2 per cent, 1 per cent, 0.5 per cent and 0.1 per cent.

The data differ in various respects. The economic unit of analysis is most often a household or family, but in one case (China) the unit is individuals — of any age, and for France and the UK it is an adult individual.29 Distribution information is usually reported for the share of wealth

27 Country-level wealth inequality statistics could potentially be used as regressors in studies e.g. of economic growth or political stability. They may also be useful in the assessment of the success of financial systems and public policies to encourage personal wealth. However, we would hope that researchers will show appropriate restraint in their use of our country-level estimates where they are imputed rather than based on hard data.

28 In the USA for example, we have used the SCF, which is purpose-designed to estimate the distribution of wealth. It has comprehensive asset and population coverage and a sophisticated strategy for dealing with the upper tail. Estate-tax based estimates are also good in the upper tail, but are subject to a range of possible biases and do not cover the middle or bottom of the distribution (Kopczuk and Saez, 2004). The PSID collects wealth data, but it cannot compete with the SCF in estimating the overall distribution of wealth especially since there is no oversampling of the upper tail (Juster and Smith, 1999). The situation in the U.K. and Germany is somewhat similar, both having panel studies (BHPS and SOEP respectively—see Sierminska et al., 2006) with similar limitations to the PSID. For the U.K. we use estate-multiplier data, which is good in the upper tail and is on a per-adult basis. For Germany we have used the EVS survey conducted by the federal statistical office. The EVS has a large sample, strong weighting procedures, and detailed asset coverage (Hauser and Stein, 2006)

${ }^{29}$ New Zealand uses the "economic unit", defined as an unpartnered adult or a couple. This is effectively a narrowly defined family. A "family" includes a group of people living together who are related by blood or marriage. A 
owned by each decile, together with the share of the top 5 per cent and the top 1 per cent of wealth-holders. But this pattern is far from universal. In some instances information on quantile shares is very sparse. On other occasions, wealth shares are reported for the top 0.5 per cent or even the top 0.1 per cent in the cases of Denmark, France, Spain, and Switzerland.

The most important respect in which the data vary across countries is the manner by which the information is collected. Household sample surveys are employed in 15 of the 20 countries. 30 Survey results are affected by sampling and non-sampling error, as discussed earlier. Non-sampling error tends to reduce estimates of inequality and the shares of the top groups because wealthy households are less likely to respond, and because under-reporting is particularly severe for the kinds of financial assets that are especially important for the wealthy—-for example, equities and bonds.

Other wealth distribution estimates derive from tax records. The French and UK data are based on estate tax returns, while the data for Denmark, Norway, and Switzerland originate from wealth tax records. These data sources have the advantage that 'response' is involuntary, and under-reporting is illegal. However, under-reporting may occur nonetheless, and there are valuation problems that produce analogous results.

Wealth tax regulations may assign to some assets a fraction of their market value, and omit other assets altogether. There are also evident differences in the way that debts are investigated and recorded. For most countries the bottom decile of wealth-holders is reported as having positive net wealth, but in Sweden the bottom three deciles each have negative net worth and in Denmark this is true for the bottom four deciles. 31

"household" is a broader concept, including a group of people sharing a common dwelling unit. Definitions differ slightly across countries and may be operationalized in different ways.

30 The list of countries differs a little from that used in Sections 2 and 3. Here the desire is to exploit distributional information for as many countries as possible, so countries with data considerably earlier than 2000 were added: Ireland (for 1987) and Korea (for 1988). In the absence of any better alternatives for these two countries, we take the shape of the wealth distribution from the late 1980s to be a guide for the wealth distribution in year 2000. Sweden was also added since its distributional detail is of interest, although the mean from this source was not judged sufficiently reliable to be used in our estimates of wealth levels. The Netherlands was dropped due to insufficient distributional detail.

31 Klevmarken (2006: 276-94) identifies a number of factors that helped to account for negative wealth shares of Swedish households in the tax register data in the 1990s, and may still have been operative in 2002. These include student loan debt, the inclusion of debt incurred to buy assets that are not covered in the data (mainly consumer 
Table 7 shows that estimated wealth concentration varies significantly across countries but is generally very high. Comparisons of wealth inequality often focus attention on the share of the top 1 per cent. That statistic is reported for 11 countries, a list that excludes China, Germany, and the Nordic countries apart from Denmark. Estimated shares of the top 1 per cent range from 10.4 per cent in Ireland to 34.8 per cent in Switzerland, with the USA towards the top end of this range at 32.7 per cent. 32 The share of the top 10 per cent, which is available for all 20 countries, ranges from 39.3 per cent in Japan to 76.4 per cent in Denmark.

The differences in wealth concentration across countries in Table 7 are attributable in part to differences in data quality. In the case of survey data it is important to over-sample in the upper tail to get the best possible estimates of top wealth shares. However, this is done in a minority of cases - -just Canada, Germany, Spain and the USA in the data used here. In the absence of oversampling in the upper tail, Davies (1993) concludes on the basis of evidence for Canada and the USA that the share of the top 1 per cent may be under-estimated by about 5 - 10 percentage points. (See Davies, 1993, pp. 168-171 and p.176.) The surprisingly low top shares seen here in some countries, for example Ireland, may reflect this phenomenon.33

durables) and a household definition in which young adults living at home with their parents, as well as unmarried cohabiting adults, were counted as separate households.

32 The sampling frame for the USA survey excludes the Forbes 400 richest families; adding them would raise the share of the top 1 per cent by about two percentage points; see Kennickell (2006: 20). Note also that this estimated share is higher than that found in estate-multiplier data for the USA. See Kopczuk and Saez (2004) who report a share of the top $1 \%$ of adults in the USA in the year 2000 of $20.8 \%$ using estate-tax data. There are differences in asset coverage between the SCF and the estate-multiplier estimates, as well as problems of tax evasion and avoidance in the estate-tax data. In addition the SCF uses a family rather than adult unit. As discussed by Kopczuk and Saez, it is widely believed that the SCF provides a better snapshot of the distribution of wealth than the estate-multiplier data at a point in time. However, the estate-multiplier data, which go back to 1916, have no rival in attempts to trace the evolution of the USA wealth distribution over long spans of time.

33 Low top shares are also seen in some of the data we have rejected for countries with multiple sources. Shares of the top $10 \%$ of $45 \%$ and $64 \%$ are seen in the UK's BHPS for 2000 and the PSID (USA) for 2001 respectively (Sierminska et al., 2006, Table 9), figures that are both lower than the estimates seen in our Table 7. Neither the BHPS nor the PSID over-samples the upper tail, whereas Table 7 shows estate-tax based data for the UK, which do not have a sampling problem in the upper tail, and SCF data for the USA, which over-sample the upper tail carefully. The German SOEP for 2002 shows higher top shares than the EVS used in our Table 7 but the SOEP results are distorted by the fact that most financial assets and non-housing debt are only recorded for values exceeding 2,500 euros, which exaggerates inequality (see Sierminska et al., 2006 again). 
As evident from Table 7, the available sources provide a patchwork of quantile shares. In order to move towards an estimate of the world distribution of wealth, more complete and comparable information is needed on the distribution in each country. To achieve this, missing cell values were imputed using a programme developed at UNU-WIDER which constructs a synthetic sample of 1000 observations that conforms exactly with any valid set of quantile shares derived from a distribution of positive values (e.g., incomes) (see Shorrocks and Wan 2008.) ${ }^{34}$ To apply this 'ungrouping' programme, the negative wealth shares reported for Denmark, Finland, Germany, and Sweden were discarded, together with the zero shares reported elsewhere, thus treating the cell values as missing observations.

The 20 countries for which wealth distribution data are available include China and India, and hence cover a good proportion of the world population. They also include most of the large rich countries, and therefore cover most global wealth. However, the fact that the list is dominated by OECD members cautions against extrapolating immediately to the rest of the world.

For most countries lacking direct wealth distribution data, the pattern of wealth distribution was estimated using income distribution data recorded in the WIID dataset, on the grounds that wealth inequality is likely to be correlated-possibly highly correlated-with income inequality across countries. The WIID dataset covers 144 countries and has multiple observations for most of them. Where possible, data was chosen for household income per capita across individuals for a year close to 2000, with first priority given to figures on disposable income, then consumption or expenditure. Eighty-five per cent of the income distributions conform to these criteria. Figures for gross incomes added a further seven per cent, leaving a residual eight per cent of countries for which the choices were very limited. The 'ungrouping' programme was then used to generate quantile shares for income (reported in Lorenz curve form) according to the same template employed for wealth distribution.

The common template applied to the wealth and income distributions allows Lorenz curve comparisons for each of the 20 reference countries listed in Table 7. In every instance, wealth

34 The first stage of the procedure fits a Lognormal distribution to the reported data and generates an equalweighted synthetic sample of 1000 observations which is approximately consistent with the recorded quantile shares. The second stage adjusts the values of the observations within each quantile until the quantile shares for the synthetic sample exactly match the true figures. Although other theoretical functional forms tend to provide a better initial fit to wealth distributions, particularly in the upper tail, the second stage 'stretching' procedure improves the accuracy of the Lognormal-based sample so much that the outcome is as good as, if not better than, the usual alternatives. 
shares are lower than income shares at each point of the Lorenz curve: in other words, wealth is unambiguously more unequally distributed than income. Furthermore, the ratios of wealth shares to income shares at a given percentile are roughly similar across countries, suggesting that income inequality can be used to generate an imputation for wealth inequality when wealth distribution data are not available. Thus, in our imputations, the ratio of the Lorenz ordinates for wealth compared to income is taken to be constant across countries. These constant ratios (14 in total) correspond to the average value recorded for the 20 reference countries. 35 This generates estimates of wealth distribution for 124 countries to add to the 20 original countries which have direct evidence of wealth inequality.

The group of 144 countries with actual or estimated wealth distribution data differs slightly from the group of 150 nations which have figures for mean wealth derived from actual data or the regressions of Section 3. Distributional evidence is more common for populous countries, so the group of 144 now includes Cuba, Iraq, Myanmar, Nepal, Serbia, Sudan, and Uzbekistan, and covers 96.6 per cent of the global population. For the rest of the world not covered by WIID data, the default of disregarding the remaining countries was again eschewed in favour of imputing a wealth distribution pattern equal to the (population weighted) average for the corresponding region and income class.

\section{$5 \quad$ World distribution}

In this section we present our estimate of the global distribution of wealth on a PPP basis. Subsequently we test the sensitivity of this estimate to the use of PPP rather than official exchange rates, and to the use of imputed data. The latter exercise allows us to present an estimate of the distribution of wealth for just the 20 countries, with $59 \%$ of the world's adult population, that have hard data. First, however, we consider the choice of unit to be used in these exercises.

The interpretation of data on personal wealth distribution depends on the underlying population deemed to be relevant. Are we interested in the distribution of wealth across all individuals, adult persons, or households or families?36 When examining the analogous issue

35 To circumvent aggregation problems, the adjustment ratio was applied to the cumulated income shares (i.e. Lorenz values) rather than separate quantile income shares.

36 Note that each of these bases was used by at least one country listed in Table 6 . 
of global income distribution, it is common practice to assume (as a first approximation) that the benefits of household expenditure are shared equally among household members, and that each person should be weighted equally in the overall distribution. However, the situation with wealth is rather different. Personal assets and debts are typically owned by named individuals, and may well be retained by those individuals if they leave the family. Furthermore, while some household assets, especially housing, provide a stream of communal benefits, it is highly unlikely that control of assets is shared equally by household members or that household members will share equally in the proceeds if the asset is sold. Membership of households can be quite fluid (for example, with respect to children living away from home) and the pattern of household structure varies markedly across countries. These aspects all argue for the use of an individual unit rather than the household or family. There is an additional, practical, reason for not using households, which is that the number of households is unknown for most countries, whereas adult population data are readily available. Finally, those under about 20 years of age have little formal or actual wealth ownership, and should therefore likely be set aside. Thus, despite the fact that most of the datasets listed in Table 7 are constructed on a family or household basis, our goal is to estimate the distribution of global wealth on a per-adult basis.

In estimating the global distribution we assume, in effect, that the shape of the adult distribution of wealth at country level is the same as that of a family- or household-based distribution. Adult and household distributions would indeed have the same shape if children held insignificant assets, the number of adults per household did not vary systematically with wealth, and wealth were equally divided among adults in a household. Children do have little wealth. However, wealthier households on average have more adults, and although there has been a trend towards more equal division of assets within marriage, equal division is not universal. Studies have looked at what happens when, starting with adult data, one "pairs up” a portion of adults into couples and measures inequality on a family basis. This reduces inequality among married people, but increases measured inequality between singles and couples. The effects are to an extent offsetting, but the net effect is to reduce measured inequality somewhat.37 This impact should be borne in mind in interpreting our estimate of global wealth inequality.

37 Wolff and Marley (1989) compared the share of wealth held by the top one percent of adults in USA estatemultiplier data with a lower-bound estimate of the share held by the top one percent of families, derived from the estate-multiplier data via assortative mating assumptions. As reported by Wolff (2002, p. 82), they found a share for the top $1 \%$ of adults of $19.1 \%$ vs. $12.7 \%$ for families in 1976 . Atkinson and Harrison (1978, p. 248) found a smaller 


\subsection{Global Distribution}

In order to get an estimate of the global distribution of wealth the national wealth levels derived in Section 3 were combined with the wealth distribution data derived in Section 4. Specifically, the ungrouping programme was applied to each country to generate a sample of 1,000 synthetic individual observations consistent with the (actual, estimated or imputed) wealth distribution. These were scaled up by mean wealth, weighted by the adult population size of the respective country, and merged into a single dataset comprising over 200,000 observations. 38 The complete sample was then processed to obtain the minimum wealth and the wealth share of each percentile in the global distribution of wealth. The procedure also provides estimates of the composition by country of each wealth percentile, although these are rough estimates given that the population of each country is condensed into a sample of 1,000 , so that a single sample observation for China or India represents more than half a million adults.

Tables 8 and 9 summarize our estimates of the distribution of wealth across the global population of 3.7 billion adults. Only $\$ 8,635$ was needed in order to belong to the top half of the world wealth distribution in the year 2000; but to be a member of the top 10 per cent required at least $\$ 89,569$ and membership of the top 1 per cent required more than $\$ 518,364$ per adult. This latter figure is surprisingly high, given that the top 1 per cent group contains 37 million adults and is therefore far from an exclusive club. The entrance fee has no doubt grown higher still in the period since the year 2000. The figures for wealth shares show that the top 10 per cent of adults owned 70.7 per cent of global household wealth, so that the typical member of this group had 7.1 times the average global holding. The corresponding figures for the top 5 per cent and top 1 per cent are 56.7 per cent (11.4 times the average) and 31.6 per cent (31.9 times the average), respectively. This contrasts with the bottom 30 per cent of the distribution, which collectively owned just one per cent of global wealth. Thus the top one per cent owned about 32 times as much as the bottom three deciles.

effect using U.K. data —a maximum decline from $30.8 \%$ to $25.6 \%$ in the share of the top $1 \%$ in going from an adult to family basis. Frick et al. (2007) compare individual and household distributions of wealth using the 2002 German SOEP survey. (It is very unusual for wealth survey data to allow such a comparison). Gini coefficients are .787 for individuals and .734 for households, but this again gives an upper bound on the difference that interests us. The Frick et al. calculation is on a per capita basis, which gives lower inequality for households than would be obtained with the conventional equal weighting of households.

38 There are 229 countries in total, but a number of small countries with identical imputed wealth levels and distributions were merged at this point. 
Table 9 gives wealth Gini coefficients for the larger countries and for the world as a whole. As mentioned earlier, wealth distribution is unambiguously more unequal than income distribution in all countries which allow comparison. The wealth Gini coefficient estimates for individual countries in Table 9 range from a low of 0.547 for Japan to the high values reported for Brazil (0.784) and the USA (0.801). Appendix IV indicates that Switzerland, whose distribution is based on hard data with good detail in the upper tail, has a Gini coefficient of 0.803.39 The USA and Switzerland have Gini coefficients close to the global wealth Gini of 0.802. Note that as is true within countries, the global figure is considerably higher than the values computed for the global income distribution. Milanovic (2005: 108) reports a Gini coefficient of 0.642, for example, for the world distribution of income in 1998 on a PPP basis.

Table 8 provides the regional representation in the various wealth quantiles. The top end of the global wealth distribution is dominated by North America, Europe and the rich AsiaPacific countries, with Europe having 35 per cent of the members of the top decile, and North America and rich Asia-Pacific each contributing just above 20 per cent. The North American share rises rapidly in the upper tail, to 39 per cent in the top percentile, overtaking Europe whose share declines to 31 per cent.

The middle half of the distribution is the domain of China, which supplies a third of the membership of deciles 4-8. In contrast, India is concentrated at the lower end of the global wealth distribution; the membership share is almost a quarter (21.9 per cent, in fact) for the bottom three deciles, and then declines monotonically with wealth right up to the top tail. The membership pattern of India is roughly similar to that of Africa.

Residents of Latin America and the Caribbean are spread across the entire global distribution, reflecting the great inequality of wealth-holding in that region. Taken as a whole, Asia-Pacific countries apart from China and India are also quite evenly spread, although there is high polarization, with rich Asia-Pacific countries occupying the top end and the lower income countries (especially, Indonesia, Bangladesh, Pakistan, and Vietnam) being found in the lower tail.

Table 9 provides more details for those countries that have either high wealth (more than one per cent of global wealth or more than one per cent of members of the world top wealth

39 We saw earlier that Switzerland had the highest share of the top 1\% for the countries with hard data on that share, shown in Table 7. Dell et al. (2005) discuss the causes of Switzerland's high wealth inequality. 
decile) or else adult populations exceeding 45 million. A country's ranking in the global top wealth decile depends on a combination of three factors: population size, mean wealth, and wealth inequality. The USA heads the list, with 19.4 per cent of the world's top decile and 36.8 per cent of the top percentile. Large population, high mean wealth, and high wealth inequality all reinforce each other in the USA case to produce this result. Japan comes a strong second to the USA, with 14.1 per cent of the top decile and 12.0 per cent of the top percentile. This strong performance reflects not only Japan's population size, but also its high personal saving rate and resulting high household asset levels. Germany, the UK, and Italy follow Japan with 7.0, 5.9 and 5.8 per cent of the top decile respectively, accounting for more than half of the 35.2 per cent population share of Europe in the top global decile. Note also that Italy, like Japan, has very low representation in the bottom half of the world distribution, and in particular relatively fewer members than the USA, Germany or the UK. This reflects, in part, the remarkably low level of household debt in Italy.

Table 9 also reports figures for median wealth across countries, which reflect variations in both mean wealth and inequality. One interesting observation is that median wealth rarely exceeds 50 per cent of mean wealth. In addition, the rank order of countries changes significantly when medians are used instead of mean values. Of the countries listed in the table, the USA ranked first in mean wealth per adult, followed by the UK, Japan, and then Italy. However, of this group, Japan ranks first in terms of median wealth per adult, followed by Italy, the UK, and then the USA. Indeed, Japan's median wealth was more than double the figure for the USA although its mean wealth was 22 per cent lower.

Missing from Table 9, of course, are the world's smaller countries, some of which are of special interest. (See Appendix IV for details on all countries.) For example, some of the countries with very high wealth rankings have much less spectacular income rankings. Hong Kong and Ireland are examples of this. Also, some countries rank very high in per capita income but are not close to the top of the wealth rankings. This is perhaps most notable for the Nordic countries: Norway, Sweden, Denmark, Finland and Iceland. A possible explanation is that strong public infrastructure and social programmes in these countries make it less necessary for people to build up personal assets than in countries where there is less public wealth and social insurance.

\subsection{Sensitivity of Global Estimate to Assumptions and Imputations}

We need to check the sensitivity of the global estimate to some key assumptions and to the use of imputed data. In checking the latter aspect we will examine the distribution of wealth for just the 20 core countries for which we have hard data. 
We begin by checking the sensitivity of our results to the use of PPP rather than official exchange rates. The first two rows of Table 10 show global estimates prepared on these alternative bases. By lowering the wealth levels of poorer countries, the shift from PPP to official exchange rates leads to a significant rise in measured inequality. The share of the top decile increases from 70.7 to 85.1 per cent, and the share of the top percentile from 31.6 to 40.1 per cent. The world Gini coefficient jumps from 0.802 to 0.892 , now far exceeding the figure recorded for any individual country. 40 The use of official exchange rates may thus be viewed as magnifying wealth level differences across countries and ensuring that intercountry variations make a greater contribution to global wealth inequality. 41

In contrast, Table 10 shows that the assumptions used during the course of our analysis have very little impact on global wealth distribution. Rows 3-5 report the PPP figures corresponding to row 1 after omitting countries for which data has been imputed from regionincome group averages. Row 3 discards those with imputed wealth levels; row 4 those without income distribution data (and hence no way of estimating wealth inequality); and row 5 those with either form of imputation. The results show that the regional-income group imputations affect less than 6 per cent of the global adult population and less than 3 per cent of global wealth, so it is perhaps not surprising to discover no discernible impact on the global wealth distribution.

The last two rows take an even more extreme position, excluding all countries except the 20 nations listed in Table 6 which have wealth distribution data. Restricting attention to these 20 countries loses 25 per cent of the world's wealth and 41 per cent of the world's adults. Nevertheless, the figures in row 6 for our core group of 20 countries are little different from the row 1 benchmark, with a top 1 per cent share of 31.7 per cent compared to 31.6 per cent, for example, and a Gini coefficient of 0.796 compared to 0.802 .

40 This parallels the result in Milanovic (2005) for the global income distribution. Milanovic has a world income Gini coefficient in 1998 of 0.642 on a PPP basis but 0.795 using official exchange rates.

41 The particular approach to estimating PPPs used in the Penn World Tables, the Geary-Khamis method, may also have an effect on our results. While it is widely used in the study of international differences in income this method produces smaller estimated differences in living standards between rich and poor countries than some other popular methods, for example the EKS method used by the World Bank (see, for example, United Nations 2007.) Using PPPs based on the Geary-Khamis method likely leads to lower estimates of world wealth inequality than would be obtained using the EKS method. 
The final row 7 keeps the same 20 core countries but discards the 'true' wealth distribution figures, replacing them instead with the estimate derived from income distribution data that was applied to most countries. Comparing rows 6 and 7 suggests that the estimation procedure reduces wealth inequality at the very top of the distribution, with the share of the top 1 per cent falling from 31.7 per cent to 27.4 per cent. However, the share of the top two quintiles rises and the share of the bottom three quintiles falls, suggesting a shift towards greater inequality. The combined impact is evidently small, with the world Gini coefficient changing from 0.796 to 0.801 . Overall, it seems that our method of estimating wealth distributions from income distributions, and the other estimation and imputation procedures used during the course of our study, have little impact on the global wealth inequality figures. The impact is certainly less than the change induced by switching from PPP figures to official exchange rate valuations, which is a conceptual distinction rather than an assumption adopted for computational convenience.

Other respects also lead us to believe that our estimates of the top wealth shares are reasonable. The survey data on which most of our estimates are based under-represent the rich and do not reflect the holdings of the super-rich. This suggests that our estimated shares of the top percentile and top decile, for example, may err on the low side. A rough idea of the possible size of the error is given by the total wealth of the world's billionaires reported by Forbes magazine for the year 2000, which was \$2.16 trillion. This represents 1.7 per cent of our figure of \$125.6 trillion (at official exchange rates) for total world household wealth. Thus if our estimates erred so badly as to exclude all the world's billionaires, the shares of the top percentile and top decile would be depressed by less than two percentage points.

As discussed in Davies et al. (2008), a further check was accomplished by fitting a Pareto distribution to the upper tail of our estimated global wealth distribution (based on official exchange rates). The Pareto distribution well approximates the upper tail of both income and wealth distribution data at the national level, and is a remarkably close fit to our global distribution in the range from $\$ 250,000$ to $\$ 5$ million. While the fit deteriorates at $\$ 10$ million, it gives us added confidence in the quality of our estimated distribution up to this point, which covers all but a very small percentage of the world's population.

\section{Conclusion}

This paper has found that the global distribution of household wealth is highly concentrated. Using PPP valuations, we estimate that the top 10 per cent of adults in the world owned 71 per cent of household wealth in the year 2000 and that the Gini coefficient for global wealth holdings was 0.802 . Measured wealth inequality is higher still if international comparisons are 
based on official exchange rates, which is appropriate if attention is focused on the rich and super rich: the share of the top decile rises to 85 per cent and the Gini coefficient becomes 0.892. These statistics indicate that the world's wealth distribution is considerably more unequal than its income distribution, for which Milanovic (2005) reports Gini coefficients of 0.642 and 0.795 on PPP and exchange rate bases, respectively. The estimated distribution is little altered if we restrict attention to the 20 core countries with hard data that have $59 \%$ of the world's adult population. For this core group the Gini coefficient of wealth is 0.796 on a PPP basis.

This study began by assembling information on household wealth levels and portfolio composition for as many countries as possible. Wealth levels vary widely and we find that the wealth/income ratio for countries rises with income or wealth, so that international wealth differences are greater, relatively speaking, than those for income. Also, we find that the correlation of national income and wealth, while strong, is not perfect. The wealthiest countries include some, like Ireland and Hong Kong, that rank significantly lower according to per capita income. Similarly, some countries with very high incomes, such as the Nordic group, rank much lower according to wealth. This finding calls attention to the fact that while greater wealth is desirable ceteris paribus, it may not be a blessing if higher personal wealth is due to pure asset price inflation (e.g. house prices) or if the higher wealth is needed to compensate for deficiencies in public infrastructure, pensions or social insurance programmes. The relatively low ranking of the Nordic countries may therefore be viewed as a positive reflection of high quality public services and programmes.

Wealth composition was seen to vary, not only with the stage of development, but across countries at similar income levels. These variations may be explained in terms of institutional and traditional differences, varying importance of public pensions, and other factors. The importance of both financial assets and borrowing rises sharply with per capita income and with financial market development. Conversely, household balance sheets in poor countries remain dominated by land and other tangible assets.

Using regression analysis and other imputation methods, mean wealth levels were assigned to countries lacking adequate wealth data. This generates estimated wealth levels for 229 countries and a snapshot of what Milanovic (2005) and others refer to as international inequality', that is inequality between countries. On a PPP basis, wealth per adult for most countries fell between the figure of \$12,021 for India and \$201,319 for the United States in the year 2000. The between-country Gini coefficient for wealth per adult was 0.533 compared to 0.448 for GDP per adult. 
Having obtained estimates of wealth level by country, details of the shape of the wealth distribution were assembled for as many countries as possible. The data covered 20 countries, which together account for 59 per cent of the world population in 2000 and, we estimate, 84 per cent of global wealth. Wealth inequality varies widely across these countries but is always greater than income inequality. The group includes all the populous rich countries along with the largest developing nations, China, India and Indonesia. It allows us to study the relation between wealth distribution and income distribution, and to generate rough estimates of wealth inequality for 124 countries that have income distribution data but no wealth distribution data. Simple imputations of wealth inequality were applied to the remaining countries, which comprised less than four per cent of the world population. Combining the wealth distribution estimates with the wealth level numbers, and weighting by population, then yielded our estimates of the world distribution of wealth.

Our estimate of 0.802 for the world wealth Gini coefficient is high, both compared to the Gini values for many countries, and compared to Gini values that have been estimated for the world distribution of income. However, it is interesting to note that some countries have similarly high values of wealth Gini coefficients. Among countries with hard data these include the USA at 0.801 and Switzerland at 0.803. According to the Gini coefficient, therefore, such countries contain within their borders about the same level of wealth inequality as is seen in the world as a whole.

Our results also allow us to comment on the relative importance of between- vs. withincountry wealth inequality. As reported earlier, between-country differences in wealth per adult yield a Gini coefficient of 0.533 on a PPP basis. Adding within-country differences pushes the Gini coefficient to 0.802, suggesting that within-country differences are a very important component of world wealth inequality. This impression is confirmed by comparison with the world income distribution results of Milanovic (2005), which show a betweencountry Gini coefficient of 0.531 and a full Gini coefficient of 0.641 in 1998 (for a common sample of countries over the years 1988-98). The Milanovic results thus show betweencountry income inequality equal to 83 per cent of total inequality, which is much greater than the 71 per cent obtained here for wealth.

We have discussed the regional aspect of global wealth distribution as well, pointing out the dominance of North America, Europe and the rich Asia-Pacific countries in the top global percentiles. The popular press sometimes suggests that high wealth individuals from emerging market economies - especially China, India and Russia_are already strongly represented among the world's rich. Our figures indicate that at least as of the year 2000 the emerging market economies did not supply a significant share of the top 1\% of global wealthholders. With the possible exception of China they appear unlikely to do so for some time. 
While this paper makes a start in estimating the world distribution of wealth, it is clear that there are gaps in the data and significant concerns about data quality in some countries. Globally, there is great room for improvement in the study of household wealth. Household balance sheets and wealth surveys need to be generated in many more countries. These are completely lacking in Latin America, and almost totally absent in Africa. The development of financial institutions and property rights are key aspects of economic growth and human development. Without the relevant data it is impossible to see what progress is being made. Improvements in data quality, particularly in survey data, must also occur. The task is far from hopeless, however, and great strides have been taken in several countries. The fact that regular wealth surveys are conducted in the two largest developing countries, China and India, is encouraging. As balance sheet studies spread, and as more and better surveys are conducted, a better picture will emerge of the level, composition and distribution of household wealth around the globe. 


\section{References}

Alvaredo, F., and E. Saez (2006). 'Income and Wealth Concentration in Spain in a Historical and Fiscal Perspective’, CEPR Discussion Paper 5836, Centre for Economic Policy Research: London.

Ammermüller, A., A. Weber, and P. Westerheide (2005). Abschlussbericht zum Forschungsauftrag des Bundesministeriums für Gesundheit und Soziale Sicherung: Die Entwicklung und Verteilung des Vermögens privater Haulshalte unter besonderer Berücksichtigung de Produktivvermögens. Zentum für Europäische Wirtscaftsforschung.

Aron J., and J. Muellbauer (2004). 'Revised Estimates of Personal Sector Wealth for South Africa', CSAE WPS 2004-24.

Aron, J., J. Muellbauer, and J. Prinsloo (2008). 'Estimating the Balance Sheet of the Personal Sector in an Emerging Market Country, South Africa 1975-2005', in Davies (2008), 196223.

Atkinson, A.B. (2008). 'Concentration among the Rich’, in Davies (2008), 64-89.

Atkinson, A.B. and A.J. Harrison (1978), Distribution of Personal Wealth in Britain, Cambridge University Press: Cambridge.

Australian Bureau of Statistics (2005). 'Household Income and Income Distribution', available from: www.abs.gov.au

Babeau, A., and T. Sbano (2003). 'Household Wealth in the National Accounts of Europe, the United States and Japan’, OECD Statistics Working Papers 2003/2, OECD: Paris.

Banco de Espana (2005) 'Survey of Household Finances (EFF): Description, Methods and Preliminary Results’, Economic Bulletin January.

Benzoni, L., P. Collin-Dufresne and R.S. Goldstein (2007), 'Portfolio Choice over the LifeCycle when the Stock and Labor Markets Are Cointegrated', Journal of Finance 62: 21232167.

Bertaut, C.C., and M. Starr-McCluer (2002), 'Household Portfolios in the United States', in L. Guiso, M. Haliassos, and T. Jappelli (eds), Household Portfolios, MIT Press: Cambridge MA.

Board of Governors of the Federal Reserve System (2003). Guide to Flow of Funds Accounts, Volume 1, Board of Governors of the Federal Reserve System: Washington DC.

Bottazzi, R., T. Jappelli and M. Padula (2006). 'Retirement expectations, pension reforms, and their impact on private wealth accumulation', Journal of Public Economics 90: 21872212.

Bourguignon, F., and C. Morrison (2002). 'Inequality Among World Citizens: 1820-1992', American Economic Review 92: 727-44. 
Brandolini, A., L. Cannari, G. D’Alession, and I. Faiella (2004). 'Household Wealth Distribution in Italy in the 1990s', Termi di discussione 530, Bank of Italy: Rome.

Browning, M., and T. Crossley (2001), “The Life-Cycle Model of Consumption and Saving”, Journal of Economic Perspectives 15: 3-22.

Cagetti, M. And M. De Nardi (2008), 'Wealth Inequality: Data and Models', Macroeconomic Dynamics 12 (Supplement 2): 285-313.

Cardoso F., and V.G. da Cunha (2005). 'Household Wealth in Portugal 1998-2004', Bank of Portugal Working Paper 4-05, Bank of Portugal: Lisbon.

Commission of the European Communities, International Monetary Fund, Organisation for Economic Co-operation and Development, United Nations, and World Bank, System of National Accounts 1993, http://unstats.un.org/unsd/sna1993/toctop.asp.

Davies, J.B. (1993). 'The Distribution of Wealth in Canada', Research in Economic Inequality 4: 159-80.

Davies, J.B. (ed.) (2008), Personal Wealth from a Global Perspective, Oxford University Press: Oxford.

Davies, J.B., and A.F. Shorrocks (2000). 'The Distribution of Wealth', in A.B. Atkinson and F. Bourguignon, Handbook of Income Distribution, Volume I, Elsevier: Amsterdam.

Davies, J.B., and A. Shorrocks (2005). 'Wealth Holdings in Developing and Transition Countries', paper presented at the workshop on Construction and Usage of Comparable Microdata on Wealth organized by the Luxembourg Wealth Study and the Bank of Italy, 27-29 January, Perugia.

Davies, J.B., S. Sandström, A. Shorrocks, and E.N. Wolff (2008). 'The World Distribution of Household Wealth', in Davies (2008), 395-418.

Deaton, A. (1995), 'Data and Econometric Tools for Development Analysis', in Jere Behrman and T.N. Srinivasan, Handbook of Development Economics, Vol. IIIA, Washington, D.C.: 1785-1882.

Deaton, A. (2005), 'Franco Modigliani and the life-cycle theory of consumption', Banca Nazionale del Lavoro Quarterly Review 58: 91-107.

Dell, F., T. Piketty, and E. Saez (2005). 'Income and Wealth Concentration in Switzerland over the $20^{\text {th }}$ Century', CEPR Discussion Paper 5090, Centre for Economic Policy Research: London.

Deutsches Bundesbank (2004). 'Financial Accounts for Germany 1991 to 2003', Special Statistical Publication 4, Deutsches Bundesbank: Berlin.

Frick, J.R., M.M. Grabka, and E.M. Sierminska (2007), "Representative wealth data for Germany from the German SOEP: The impact of methodological decisions around imputation and the choice of the aggregation unit”, SOEP Papers, DIW Berlin. 
Gale, W.G. (1998). 'The Efects of Pensions on Household Wealth: A Reevaluation of Theory and Evidence', Journal of Political Economy 106: 706-23.

Gale, W.G., L. Muller, J.W.R. Phillips and M. Dworsky (2007). 'Effects of After-Tax Pension and Social Security Benefits on Household Wealth: Evidence from a Sample of Retirees', Brookings Institution, processed.

Goldsmith, R.W. (1985). Comparative National Balance Sheets: A Study of Twenty Countries, 1688-1978, University of Chicago Press: Chicago.

Gomes, F.J., L.J. Kotlikoff and L.M. Viceira (2008). 'Optimal Life-Cycle Investing With Flexible Labor Supply: A Welfare Analysis of Life-Cycle Funds’, NBER Working Paper No. 13966, April.

Greene, W.H. (1993). Econometric Analysis, Second Edition, Macmillan: New York.

Hauser, R., and H. Stein (2006), "Inequality of the distribution of personal wealth in Germany, 1973-98”, in Wolff (2006): 195-224.

Headey, B., G. Marks, and M. Wooden (2005). 'The Structure and Distribution of Household Wealth in Australia', Australian Economic Review 38: 159-75.

Inland Revenue Statistics (2005). 'Distribution of Personal Wealth', available from: www.hmrc.gov.uk/stats/personal_wealth/menu.htm

IMF (2005). 'Global Financial Stability Report, Market Developments and Issues: International Capital Markets Department', available from: www.imf.org/External/Pubs/FT/GFSR/2005/01/index.htm

Japan Statistics Bureau (2005). 'National Survey of Family Income and Expenditure 1999', available from www.stat.go.jp/english/data/zensho/index.htm

Jäntti, M., and E. Sierminska (2008). Survey Estimates of Wealth Holdings in OECD Countries: Evidence on the Level and Distribution across Selected Countries', in Davies (2008), 27-41.

Juster, T., and J. Smith (1999), “The Measurement and Structure of Household Wealth”, Labour Economics 6: 253-75.

Kennan, J. (1989). 'Simultaneous Equations Bias in Disaggregated Econometric Models', Review of Economic Studies 56: 151-56.

Kennickell, A. (2006). 'A Rolling Tide: Changes in the Distribution of Wealth in the US, 1989-2001', in E.N. Wolff (2006).

Klevmarken, A. (2006). 'On household wealth trends in Sweden over the 1990s', in E.N. Wolff (2006).

Kopczuk, W. and E. Saez (2004), "Top Wealth Shares in the United States, 1916-2000: Evidence from Estate Tax Returns”, National Tax Journal 57: 445-87. 
Leipziger, D.M., D. Dollar, A.F. Shorrocks, and S.Y. Song (1992). The Distribution of Income and Wealth in Korea, World Bank: Washington DC.

Li, S., and R. Zhao (2008), “Changes in the Distribution of Wealth in China, 1995-2002”, in Davies (2008), 93-111.

Milanovic, B. (2002). 'True World Income Distribution, 1988 and 1993: First Calculation Based on Household Surveys Alone', Economic Journal 112: 51-92.

Milanovic, B. (2005). Worlds Apart, Measuring International and Global Inequality, Princeton University Press: Princeton NJ and Oxford.

Modigliani, M. (1988). 'Life Cycle, Individual Thrift and the Wealth of Nations. American Economic Review 76:297-313.

Modigliani, M. and B. Brumberg (1954). 'Utility Analysis and Aggregate Consumption Functions: An Attempt at Integration' in A. Abel ed., The Collected Papers of Franco Modigliani, Vol. 2. MIT Press: Cambridge, 128-97.

Neary, J.P. (2004). 'Rationalizing the Penn World Table: True Multilateral Indices for International Comparisons of Real Income', American Economic Review 94: 1411-28.

Nolan, B. (1991). The Wealth of Irish Households: What Can We Learn from Survey Data? Combat Poverty Agency: Dublin.

OECD (2005). OECD National Accounts Statistics, National Accounts of OECD Countries, Volume IIIb, Financial Balance Sheets, Stocks Vol. 2005 release 02, OECD: Paris.

Piketty, T., G. Postel-Vinay, and J.-L. Rosenthal (2004). 'Wealth Concentration in a Developing Economy: Paris and France, 1807-1994', CEPR Discussion Paper 4631, Centre for Economic Policy Research: London.

Shorrocks, A., and G. Wan (2008), 'Ungrouping Income Distributions: Synthesising Samples for Inequality and Poverty Analysis', in K. Basu and R. Kanbur (eds.), Arguments for a Better World: Essays in Honor of Amartya Sen. Volume I: Ethics, Welfare and Measurement, Oxford University Press: Oxford.

Sierminska, E., A Brandolini and T. Smeeding (2006), 'Comparing Wealth Distribution Across Rich Countries: First Results from the Luxembourg Wealth Study’, Working Paper No. 1, Luxembourg Wealth Study.

Singapore Department of Statistics (2003). 'Wealth and Liabilities of Singapore Households', Occasional Paper on Economic Statistics March, Singapore Department of Statistics: Singapore.

Statistics Canada (2001). The Assets and Debts of Canadians: An overview of the results of the Survey of Financial Security, Statistics Canada: Ottawa.

Statistics Denmark (1998). Indkomster og formuer 1996, Statistics Denmark: Copenhagen. 
Statistics Finland (2000). 'Kotitalouksien varallisuus 1998', Income and Consumption 2000: 26, Statistics Finland: Helsinki.

Statistics New Zealand (2002). The Wealth of New Zealanders: A Report on Their Assets and Debts, Household Economic Statistics Division Statistics: Wellington.

Statistics Norway (2005). Income and Property Statistics for Households, available from: www.ssb.no/english/subjects/05/01/ifhus_en/

Statistics Sweden (2004). Wealth Statistics 2004, Statistics Sweden: Örebro.

Subramanian, S., and D. Jayaraj (2008). 'The Distribution of Household Wealth in India', in Davies (2008), 112-33.

UniCredit Group (2005). ‘New Europe Household Wealth Monitor’, November.

United Nations (2007). Handbook of the International Comparison Programme, Processing of the Basic Data, United Nations Statistics Division: New York.

van Els, P., W. van den End, and M. van Rooij (2005). 'Financial Behaviour of Dutch Households: Analysis of DNB Household Survey Data 2003’, BIS Papers 22, Bank for International Settlements: Basel.

Wolff, E.N. (2002), Top Heavy: A Study of Increasing Inequality of Wealth in America, newly updated and expanded edition, The New Press: New York.

Wolff, E.N. (2006). International Perspectives on Household Wealth, Edward Elgar Publishing: Cheltenham and Northampton MA.

Wolff, E.N. and M. Marley (1989), "Long-Term Trends in U.S. Wealth Inequality: Methodological Issues and Results”, in R.E. Lipsey and H.S. Tice (eds.) The Measurement of Saving, Investment and Wealth, University of Chicago Press: Chicago, pp. 765-839.

Yemtsov, R. (2007). 'Housing Privatization and Household Wealth in Transition', in Davies (2008), 312-33.

Zellner, A. (1962) 'An Efficient Method of Estimating Seemingly Unrelated Regressions and Tests of Aggregation Bias’, Journal of the American Statistical Association 57: 500-09. 
Table 1 Coverage of wealth levels data, year 2000

\begin{tabular}{|c|c|c|c|c|c|c|c|}
\hline & & High incom & & $\begin{array}{l}\text { Upper middle } \\
\text { income }\end{array}$ & $\begin{array}{c}\text { Lower middle } \\
\text { income }\end{array}$ & Low income & $\begin{array}{l}\text { Cumulative } \% \text { of } \\
\text { world population }\end{array}$ \\
\hline \multicolumn{8}{|c|}{ Complete financial and non-financial data } \\
\hline Household Balance Sheets & $\begin{array}{c}\text { North America } \\
\text { Canada } \\
\text { USA }\end{array}$ & $\begin{array}{c}\text { Europe } \\
\text { Denmark } \\
\text { Finland } \\
\text { France } \\
\text { Germany } \\
\text { Italy } \\
\text { Netherlands } \\
\text { Portugal } \\
\text { Spain }\end{array}$ & $\begin{array}{l}\text { Asia-Pacific } \\
\text { Australia } \\
\text { Taiwan } \\
\text { Japan } \\
\text { New Zealand } \\
\text { Singapore }\end{array}$ & $\begin{array}{c}\text { Czech Republic } \\
\text { Poland } \\
\text { South Africa }\end{array}$ & & & 15.3 \\
\hline Survey data & & & & & China & $\begin{array}{c}\text { India } \\
\text { Indonesia } \\
\end{array}$ & 56.0 \\
\hline \multicolumn{8}{|c|}{ Incomplete data } \\
\hline Financial Balance Sheets & & $\begin{array}{c}\text { Austria } \\
\text { Belgium } \\
\text { Greece } \\
\text { Slovenia } \\
\text { Sweden } \\
\text { Switzerland }\end{array}$ & Korea & $\begin{array}{c}\text { Croatia } \\
\text { Estonia } \\
\text { Hungary } \\
\text { Latvia } \\
\text { Lithuania } \\
\text { Slovakia }\end{array}$ & $\begin{array}{c}\text { Bulgaria } \\
\text { Romania } \\
\text { Turkey }\end{array}$ & & 59.5 \\
\hline Survey data: non-financial assets & & & & Mexico & & & 61.1 \\
\hline $\begin{array}{l}\text { Number of countries with wealth partly or } \\
\text { fully estimated by regression method }\end{array}$ & & 18 & & 28 & 36 & 46 & 95.2 \\
\hline $\begin{array}{c}\text { Number of countries with wealth imputed } \\
\text { by mean value of group }\end{array}$ & & 33 & & 17 & 22 & 9 & 100.0 \\
\hline
\end{tabular}

Source: see Appendix II. 
Table 2: Percentage composition of household wealth in household balance sheets, year 2000

\begin{tabular}{|c|c|c|c|c|c|c|c|}
\hline & \multicolumn{4}{|c|}{ Share of total gross assets } & \multicolumn{3}{|c|}{ Share of financial assets } \\
\hline & $\begin{array}{l}\text { financial } \\
\text { assets }\end{array}$ & $\begin{array}{l}\text { non-financial } \\
\text { assets }\end{array}$ & housing & Liabilities & liquid assets & equities & $\begin{array}{l}\text { other financial } \\
\text { assets }^{\mathrm{a}}\end{array}$ \\
\hline \multicolumn{8}{|c|}{ Household balance sheets } \\
\hline Australia & 41 & 59 & 20 & 17 & 22 & 20 & 58 \\
\hline Canada & 57 & 43 & 20 & 18 & 25 & 32 & 43 \\
\hline Czech Republic & 34 & 66 & $\mathrm{Na}$ & 9 & 60 & 24 & 16 \\
\hline Denmark & 55 & 45 & 24 & 30 & 21 & 31 & 48 \\
\hline Finland & 41 & 59 & 48 & 13 & 33 & 45 & 22 \\
\hline France & 40 & 60 & 29 & 11 & 33 & 32 & 35 \\
\hline Germany & 40 & 60 & 42 & 16 & 34 & 37 & 29 \\
\hline Italy & 42 & 58 & 50 & 3 & 23 & 55 & 21 \\
\hline Japan & 50 & 50 & $\mathrm{Na}$ & 14 & 53 & 16 & 31 \\
\hline Netherlands & 54 & 46 & 38 & 16 & 19 & 24 & 57 \\
\hline New Zealand & 32 & 68 & 59 & 20 & 35 & 40 & 25 \\
\hline Poland & 20 & 80 & 62 & 3 & 59 & 25 & 17 \\
\hline Portugal & 49 & 51 & 39 & 19 & 47 & 38 & 15 \\
\hline Singapore & 45 & 55 & 47 & 18 & 44 & 21 & 35 \\
\hline South Africa & 65 & 35 & 16 & 15 & 21 & 19 & 60 \\
\hline Spain & 31 & 69 & 60 & 10 & 40 & 43 & 17 \\
\hline Taiwan & 59 & 41 & 20 & 10 & 39 & 32 & 29 \\
\hline UK & 53 & 47 & 35 & 13 & 20 & 24 & 55 \\
\hline USA & 67 & 33 & 26 & 15 & 13 & 51 & 36 \\
\hline
\end{tabular}




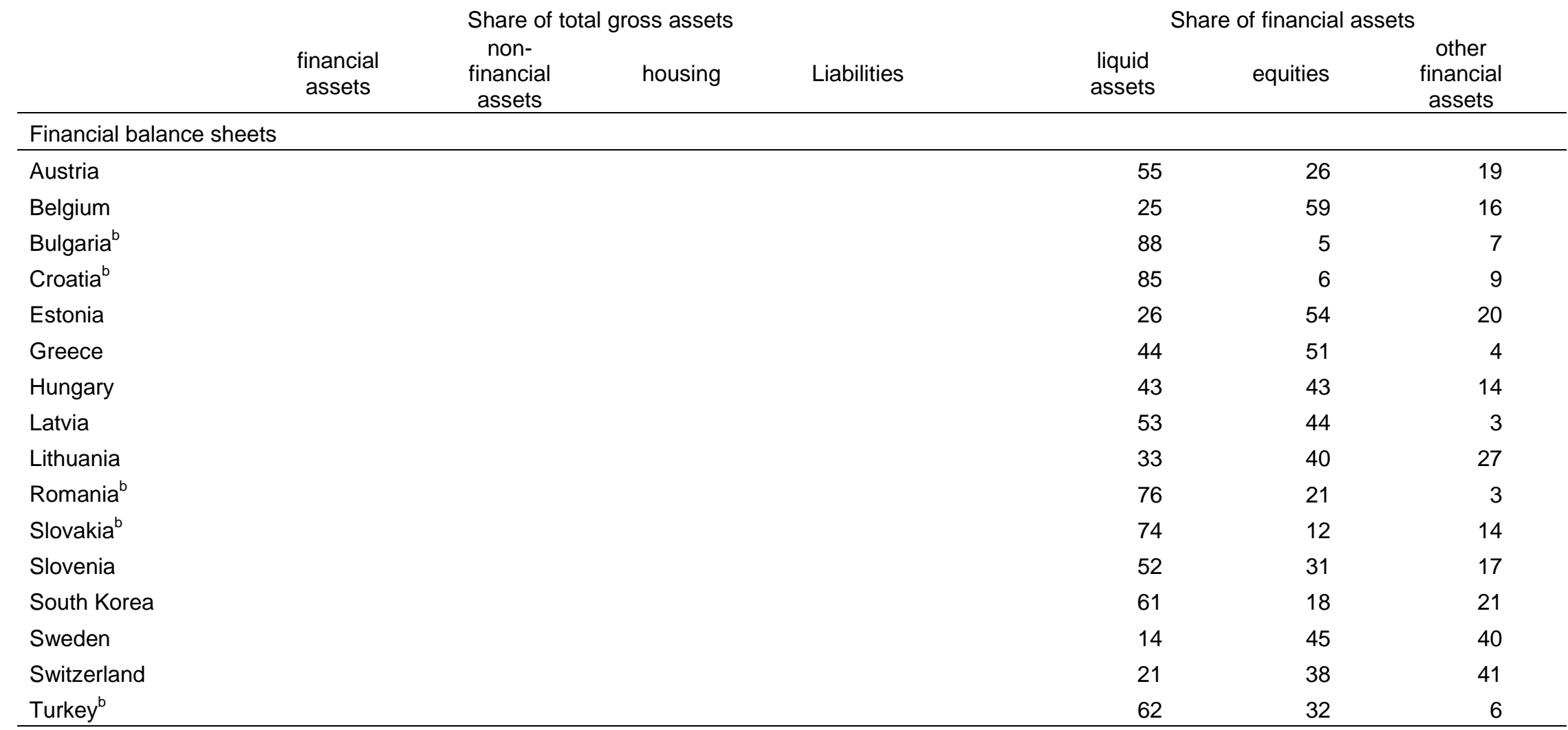

Note: ${ }^{\mathrm{a}}$ Other financial assets include insurance and pension reserves and other accounts receivable. ${ }^{\mathrm{b}}$ Composition from year 2004.

Source: see Appendix IIB. 
Table 3: Percentage composition of household wealth in survey data, year 2000

\begin{tabular}{|c|c|c|c|c|c|c|c|}
\hline & \multicolumn{4}{|c|}{ Share of total assets } & \multicolumn{3}{|c|}{ Share of financial assets } \\
\hline & $\begin{array}{l}\text { financial } \\
\text { assets }\end{array}$ & $\begin{array}{l}\text { non-financial } \\
\text { assets }\end{array}$ & housing & liabilities & liquid assets & equities & $\begin{array}{l}\text { other financial } \\
\text { assets }^{\mathrm{a}}\end{array}$ \\
\hline Australia & 32 & 68 & 54 & 14 & 14 & 21 & 64 \\
\hline Canada & 29 & 71 & 38 & 16 & 19 & 23 & 58 \\
\hline China $^{b}$ & 22 & 78 & 57 & 1 & na & na & na \\
\hline Finland & 17 & 83 & 75 & 12 & 51 & 36 & 14 \\
\hline Germany & 24 & 76 & na & 15 & 46 & 24 & 30 \\
\hline India & 5 & 95 & 28 & 3 & 92 & 5 & 3 \\
\hline Indonesia & 3 & 97 & 46 & 2 & na & na & na \\
\hline Italy & 18 & 78 & 69 & 2 & 40 & 39 & na \\
\hline Japan & 30 & 70 & 54 & 10 & 59 & 34 & 29 \\
\hline Netherlands & 21 & 80 & 70 & 27 & 37 & 43 & 20 \\
\hline New Zealand & 28 & 72 & 37 & 16 & 21 & 21 & 58 \\
\hline Spain & 13 & 87 & 58 & 9 & 40 & 38 & 22 \\
\hline USA & 42 & 58 & 32 & 12 & 15 & 39 & 46 \\
\hline
\end{tabular}

Note: ${ }^{a}$ Other financial assets include insurance and pension plans and other accounts receivable. ${ }^{\mathrm{b}}$ Housing assets are net of associated debts; liabilities exclude housing debt.

Source: see Appendix II. 
Table 4: Wealth per capita from household balance sheet and survey data, year 2000

\begin{tabular}{|c|c|c|c|c|c|c|c|c|}
\hline & \multicolumn{4}{|c|}{ US\$ per capita at PPP exchange rates } & \multicolumn{4}{|c|}{ US\$ per capita at official exchange rates } \\
\hline & Wealth $^{a}$ & $\begin{array}{l}\text { Real } \\
\text { GDP }^{b}\end{array}$ & $\begin{array}{l}\text { Personal } \\
\text { disposable } \\
\text { income }^{c}\end{array}$ & $\begin{array}{c}\text { Real } \\
\text { Consumption }^{\mathrm{b}}\end{array}$ & Wealth $^{a}$ & $\mathrm{GDP}^{\mathrm{b}}$ & $\begin{array}{l}\text { Personal } \\
\text { disposable } \\
\text { income }^{c}\end{array}$ & Consumption $^{b}$ \\
\hline \multicolumn{9}{|l|}{ Household balance sheet data } \\
\hline Mean & 84955 & 22519 & 13482 & 14240 & 74890 & 19434 & 11530 & 12239 \\
\hline Median & 90906 & 23917 & 12798 & 15197 & 70916 & 21425 & 11915 & 12708 \\
\hline Coefficient of variation & 0.440 & 0.301 & 0.331 & 0.319 & 0.612 & 0.527 & 0.524 & 0.521 \\
\hline Highest wealth: USA & 143727 & 35619 & 25480 & 24313 & 143727 & 35619 & 25480 & 24313 \\
\hline Lowest wealth: South Africa & 16266 & 8017 & 4691 & 5210 & 5977 & 2946 & 1724 & 1914 \\
\hline \multicolumn{9}{|l|}{ Survey data } \\
\hline Mean & 59349 & 20311 & 12338 & 13072 & 53251 & 17983 & 10911 & 11588 \\
\hline Median & 61218 & 23917 & 12798 & 15197 & 45176 & 20338 & 11557 & 12708 \\
\hline Coefficient of variation & 0.667 & 0.512 & 0.551 & 0.530 & 0.836 & 0.669 & 0.707 & 0.671 \\
\hline Highest wealth: USA & 143857 & 35619 & 25480 & 24313 & 143857 & 35619 & 25480 & 24313 \\
\hline Lowest wealth: India & 6513 & 2684 & 1916 & 1406 & 1112 & 458 & 327 & 240 \\
\hline Ratio high/low: HBS & 8.8 & 4.4 & 5.4 & 4.7 & 24.1 & 12.1 & 14.8 & 12.7 \\
\hline Ratio high/low: survey data & 22.1 & 13.3 & 13.3 & 17.3 & 129.4 & 77.8 & 77.9 & 101.4 \\
\hline China/USA: survey data & 12.8 & 9.3 & 13.2 & 13.0 & 55.1 & 40.0 & 56.8 & 56.1 \\
\hline
\end{tabular}

Note: ${ }^{a}$ See Appendix II for sources of HBS and survey data. Figures have been adjusted to year 2000 values using the real growth rate per capita. ${ }^{b}$ Source: Penn World Table Version 6.1. ' Source: The Economist Intelligence Unit. 
Table 5 Regressions of wealth components

\begin{tabular}{|c|c|c|c|c|c|c|c|c|}
\hline \multirow[t]{2}{*}{ Independent variables } & \multicolumn{2}{|c|}{ Log wealth } & \multicolumn{2}{|c|}{ Log non-financial wealth } & \multicolumn{2}{|c|}{ Log financial wealth } & \multicolumn{2}{|c|}{ Log liabilities } \\
\hline & (1a) & (1b) & $(2 a)$ & $(2 b)$ & (3a) & (3b) & $(4 a)$ & (4b) \\
\hline \multirow[t]{2}{*}{ Constant } & $-3.031 *$ & $-2.408 * * *$ & $-2.919 * *$ & $-1.765^{* *}$ & $-4.237 * *$ & $-4.547^{* * *}$ & $-5.726 * *$ & $-3.131 *$ \\
\hline & $(1.508)$ & $(0.680)$ & $(1.130)$ & $(0.634)$ & $(1.718)$ & $(1.133)$ & $(2.197)$ & $(1.693)$ \\
\hline Log real consumption per & $0.907^{* * *}$ & $0.886^{* * *}$ & $0.580^{* * *}$ & $0.681^{* * *}$ & $0.940 * * *$ & $1.040 * * *$ & $1.241 * * *$ & $1.199 * * *$ \\
\hline capita & $(0.182)$ & $(0.067)$ & $(0.159)$ & $(0.083)$ & $(0.201)$ & $(0.138)$ & $(0.273)$ & $(0.222)$ \\
\hline \multirow[t]{2}{*}{ Life expectancy in $1980(L)$} & $0.073^{* *}$ & $0.063 * * *$ & $0.103^{* * *}$ & $0.075^{* * *}$ & 0.043 & $0.044^{* *}$ & $-0.058 *$ & $-0.069 * *$ \\
\hline & $(0.028)$ & $(0.015)$ & $(0.028)$ & $(0.017)$ & $(0.027)$ & $(0.021)$ & $(0.035)$ & $(0.028)$ \\
\hline Average GDP per capita growth & -0.010 & & -0.048 & & $0.114^{* *}$ & $0.143^{* * *}$ & -0.086 & \\
\hline $1990-2000(g)$ & $(0.050)$ & & $(0.047)$ & & $(0.046)$ & $(0.036)$ & $(0.061)$ & \\
\hline Average population growth & 0.192 & $0.174^{* *}$ & 0.117 & & 0.073 & & $0.343^{*}$ & \\
\hline $1990-2000(p)$ & $(0.161)$ & $(0.075)$ & $(0.097)$ & & $(0.166)$ & & $(0.207)$ & \\
\hline \multirow[t]{2}{*}{ Log population density } & $0.134 * * *$ & $0.117 * * *$ & $0.134 * * *$ & $0.117 * * *$ & & & & \\
\hline & $(0.035)$ & $(0.023)$ & $(0.034)$ & $(0.029)$ & & & & \\
\hline \multirow[t]{2}{*}{ Log market capitalization rate } & 0.013 & & & & $0.403^{* * *}$ & $0.405^{* * *}$ & & \\
\hline & $(0.103)$ & & & & $(0.096)$ & $(0.084)$ & & \\
\hline Log domestic credits & & & & & & & $0.831^{* * *}$ & $0.702^{* * *}$ \\
\hline available to private sector & & & & & & & $(0.179)$ & $(0.147)$ \\
\hline \multirow[t]{2}{*}{ Urban population (\% of total) } & -0.003 & & & & 0.002 & & $0.017^{* *}$ & $0.017^{* *}$ \\
\hline & $(0.007)$ & & & & $(0.006)$ & & $(0.008)$ & $(0.008)$ \\
\hline Fixed line and mobile phone & -0.002 & & & & 0.006 & & $0.021 * * *$ & $0.015^{* *}$ \\
\hline subscribers (per 100 people) & $(0.004)$ & & & & $(0.005)$ & & $(0.006)$ & $(0.006)$ \\
\hline \multirow[t]{2}{*}{ Survey dummy } & -0.093 & & 0.061 & & $-1.331^{* *}$ & $-1.639 * * *$ & 1.061 & \\
\hline & $(0.415)$ & & $(0.251)$ & & $(0.542)$ & $(0.431)$ & $(0.681)$ & \\
\hline \multirow[t]{2}{*}{ Transition dummy } & -0.470 & $-0.430 * *$ & $-0.537 * *$ & $-0.533 * * *$ & 0.135 & & $0.719 *$ & \\
\hline & $(0.320)$ & $(0.156)$ & $(0.245)$ & $(0.179)$ & $(0.325)$ & & $(0.402)$ & \\
\hline $\mathrm{R}^{2}$ & 0.990 & 0.989 & 0.981 & 0.978 & & & & \\
\hline $\mathrm{r}^{2}$ & & & & & 0.968 & 0.966 & 0.960 & 0.953 \\
\hline RMSE & 0.212 & 0.182 & 0.233 & 0.227 & 0.377 & 0.385 & 0.483 & 0.519 \\
\hline Sample size & 22 & 22 & 23 & 23 & 38 & 38 & 38 & 38 \\
\hline
\end{tabular}

Note: The non-financial regressions use Ordinary Least Squares and a sample consisting of 19 countries with HBS data and 4 with survey data. The financial assets and liabilities regressions use the Seemingly Unrelated Regression (SUR) method and a sample consisting of 35 countries with HBS or financial balance sheet data and 3 with survey data. Standard errors are given in parentheses. Significance: * $10 \%$ level; ** $5 \%$ level; *** $1 \%$ level. $\mathrm{R}^{2}$ is not a well-defined concept in generalized least squares, so as is customary the fraction of the variance in the dependent variable that is 'explained' in each regression is referred to as ' $\mathrm{R}^{2}$ ' here.

Sources: (a) Life expectancy in 1980, gdp growth gdp per capita growth, population growth, market capitalization rate, availability of domestic credit, urban population and fixed line and mobile phone subscribers are from World Development Indicators 2005-2008. (b) Real consumption is from PWT 6.1. See Alan Heston, Robert Summers and Bettina Aten, Penn World Table Version 6.1, Center for International Comparisons at the University of Pennsylvania (CICUP), October 2002. (c) Data for Taiwan is from the National Statistical Office's website. 
Table 6: Average wealth and income by region, year 2000 (PPP\$)

\begin{tabular}{|c|c|c|c|c|c|c|c|}
\hline Region (number of countries) & $\begin{array}{l}\text { Share of world } \\
\text { population } \\
(\%)\end{array}$ & $\begin{array}{l}\text { Wealth per } \\
\text { capita }\end{array}$ & $\begin{array}{l}\text { Wealth per } \\
\text { adult }\end{array}$ & $\begin{array}{l}\text { Share of world } \\
\text { wealth } \\
(\%)\end{array}$ & GDP per capita & GDP per adult & $\begin{array}{l}\text { Share of world } \\
\text { GDP } \\
(\%)\end{array}$ \\
\hline North America (5) & 5.2 & 138417 & 193147 & 26.8 & 34947 & 48765 & 23.6 \\
\hline Latin America and Caribbean (46) & 8.6 & 19713 & 34031 & 6.4 & 7683 & 13262 & 8.6 \\
\hline Europe (48) & 12.0 & 62918 & 83336 & 28.2 & 16444 & 21780 & 25.7 \\
\hline Africa (56) & 13.4 & 4324 & 9336 & 2.2 & 2242 & 4842 & 3.9 \\
\hline China & 20.6 & 12819 & 19056 & 9.8 & 3844 & 5713 & 10.3 \\
\hline India & 16.8 & 6718 & 12021 & 4.2 & 2684 & 4802 & 5.9 \\
\hline Rich Asia-Pacific (17) & 4.0 & 101924 & 135572 & 15.3 & 23247 & 30912 & 12.1 \\
\hline Other Asia-Pacific (55) & 19.5 & 9808 & 18054. & 7.2 & 3911 & 7206 & 10.0 \\
\hline World (229) & 100 & 26738 & 44024 & 100 & 7675 & 12633 & 100 \\
\hline World between-country Gini coeff. & & 0.583 & 0.533 & & 0.503 & 0.448 & \\
\hline
\end{tabular}

Note: The world between-country Gini coefficient is the Gini inequality value computed using the per capita (or adult) wealth (or income) figures for 229 countries weighted by population size.

Source: Authors' calculations. 
Table 7: Wealth shares for countries with wealth distribution data

\begin{tabular}{|c|c|c|c|c|c|c|c|c|c|c|c|c|c|c|c|c|c|c|c|}
\hline \multirow[b]{2}{*}{ Country } & \multirow[b]{2}{*}{ Year } & \multirow[b]{2}{*}{ Unit } & \multicolumn{11}{|c|}{ Share of lowest } & \multicolumn{6}{|c|}{ Share of top } \\
\hline & & & $10 \%$ & $20 \%$ & $25 \%$ & $30 \%$ & $40 \%$ & $50 \%$ & $60 \%$ & $70 \%$ & $75 \%$ & $80 \%$ & $90 \%$ & $10 \%$ & $5 \%$ & $2 \%$ & $1 \%$ & $0.5 \%$ & $0.1 \%$ \\
\hline Australia & 2002 & household & -0.1 & 0.2 & & 1.6 & 4.4 & 8.9 & 15.4 & 24.4 & & 36.9 & 55.2 & 44.9 & 31.0 & & & & \\
\hline Canada & 1999 & family & & & & 1.0 & 3.0 & 6.0 & 11.0 & 19.0 & & 30.0 & 47.0 & 53.0 & & & & & \\
\hline China & 2002 & individual & 0.7 & 2.8 & & 5.8 & 9.6 & 14.4 & 20.6 & 28.9 & & 40.7 & 58.6 & 41.4 & & & & & \\
\hline Denmark & 1996 & family & -14.4 & -17.3 & & -18.1 & -18.1 & -17.6 & -15.8 & -10.5 & & 1.3 & 23.6 & 76.4 & 56.0 & & 28.8 & 22.2 & 11.6 \\
\hline Finland & 1998 & household & -0.9 & -0.9 & & -0.3 & 2.2 & 7.4 & 15.0 & 25.0 & & 38.6 & 57.7 & 42.3 & & & & & \\
\hline France & 1994 & adult & & & & & & & & & & & 39.0 & 61.0 & & & 21.3 & & 6.3 \\
\hline Germany & 1998 & household & -0.3 & -0.2 & & 0.3 & 1.5 & 3.9 & 9.0 & 18.9 & & 34.0 & 55.7 & 44.4 & & & & & \\
\hline India & $2002-03$ & household & 0.2 & 1.0 & & 2.5 & 4.8 & 8.1 & 12.9 & 19.8 & & 30.1 & 47.1 & 52.9 & 38.3 & & 15.7 & & \\
\hline Indonesia & 1997 & household & 0.0 & 0.4 & & 1.3 & 2.8 & 5.1 & 8.5 & 13.5 & & 21.1 & 34.6 & 65.4 & 56.0 & & 28.7 & & \\
\hline Ireland & 1987 & household & 0.0 & 0.2 & & 2.5 & 6.6 & 12.2 & 18.9 & 28.5 & & 40.4 & 57.7 & 42.3 & 28.7 & & 10.4 & & \\
\hline Italy & 2000 & household & & & & & 7.0 & & & & & 36.2 & 51.5 & 48.5 & 36.4 & & 17.2 & & \\
\hline Japan & 1999 & household & 0.5 & 2.1 & & 4.8 & 8.7 & 13.9 & 20.7 & 29.8 & & 42.3 & 60.7 & 39.3 & & & & & \\
\hline South Korea & 1988 & household & 0.5 & 1.8 & & 4.0 & 7.4 & 12.3 & 18.9 & 27.9 & & 39.9 & 56.9 & 43.1 & 31.0 & & 14.0 & & \\
\hline New Zealand & 2001 & econ. unit & & & & & & & & & & & 48.3 & 51.7 & & & & & \\
\hline Norway & 2000 & household & 0.1 & 0.7 & & 2.6 & 5.8 & 10.4 & 16.4 & 24.2 & & 34.6 & 49.6 & 50.5 & & & & & \\
\hline Spain & 2002 & household & & & 2.1 & & & 13.2 & & & 34.7 & & 58.1 & 41.9 & & & 18.3 & 13.1 & 5.6 \\
\hline Sweden & 2002 & household & -5.7 & -6.8 & & -6.9 & -6.6 & -4.8 & -0.6 & 7.1 & & 19.9 & 41.4 & 58.6 & & & & & \\
\hline Switzerland & 1997 & family & & & & & & & & & & & 28.7 & 71.3 & 58.0 & & 34.8 & 27.6 & 16.0 \\
\hline UK & 2000 & adult & & & & & & 5.0 & & & 25.0 & & 44.0 & 56.0 & 44.0 & 31.0 & 23.0 & & \\
\hline USA & 2001 & family & -0.2 & -0.1 & & 0.2 & 1.1 & 2.8 & 5.6 & 10.1 & & 17.4 & 30.2 & 69.8 & 57.7 & & 32.7 & & \\
\hline
\end{tabular}

Note: The data is reported as in the original sources and may contain rounding errors Source: See Appendix IIC. 
Table 8: Global wealth distribution per adult in 2000, regional details based on PPP exchange rates

\begin{tabular}{|c|c|c|c|c|c|c|c|c|c|c|c|c|c|c|}
\hline & \multicolumn{9}{|c|}{ Decile } & \multicolumn{3}{|c|}{ Top } & \multirow{2}{*}{$\begin{array}{c}\text { Adult } \\
\text { population } \\
\text { (million) }\end{array}$} & \multirow{2}{*}{$\begin{array}{c}\text { Adult } \\
\text { population } \\
\text { share (\%) }\end{array}$} \\
\hline & 1 & 2 & 3 & 4 & 5 & 6 & 7 & 8 & 9 & $10 \%$ & $5 \%$ & $1 \%$ & & \\
\hline World wealth shares (\%) & 0.1 & 0.3 & 0.6 & 1.1 & 1.6 & 2.4 & 3.8 & 6.3 & 13.1 & 70.7 & 56.7 & 31.6 & & \\
\hline Minimum wealth (PPP\$) & 0.5 & 735 & 1837 & 3658 & 5802 & 8635 & 13022 & 20884 & 36944 & 89569 & 172236 & 518364 & & \\
\hline \multicolumn{15}{|c|}{ Adult population proportions by region (\%) } \\
\hline North America & 1.5 & 2.8 & 3.9 & 3.5 & 3.9 & 3.8 & 4.8 & 6.0 & 9.1 & 21.7 & 25.5 & 39.1 & 225.7 & 6.1 \\
\hline Latin America and Caribbean & 10.8 & 9.1 & 8.7 & 7.2 & 6.8 & 7.0 & 8.2 & 8.7 & 8.8 & 6.5 & 5.9 & 5.9 & 302.9 & 8.2 \\
\hline Europe & 9.1 & 9.2 & 9.7 & 9.8 & 9.7 & 11.9 & 14.3 & 17.8 & 22.2 & 35.2 & 36.5 & 31.4 & 550.6 & 14.9 \\
\hline Africa & 33.1 & 19.0 & 14.4 & 9.0 & 6.3 & 5.6 & 5.2 & 4.3 & 3.4 & 1.6 & 1.2 & 1.0 & 376.3 & 10.2 \\
\hline China & 4.3 & 13.0 & 11.8 & 30.5 & 36.9 & 36.9 & 33.5 & 31.5 & 24.1 & 5.3 & 2.3 & 0.0 & 842.1 & 22.8 \\
\hline India & 18.4 & 21.9 & 25.3 & 19.6 & 17.0 & 15.9 & 14.3 & 11.6 & 7.9 & 2.5 & 1.2 & 0.0 & 570.6 & 15.4 \\
\hline Rich Asia-Pacific & 0.2 & 0.6 & 1.2 & 1.4 & 1.9 & 2.2 & 2.7 & 5.4 & 12.8 & 21.1 & 22.7 & 18.9 & 183.3 & 5.0 \\
\hline Other Asia-Pacific & 22.6 & 24.4 & 24.8 & 19.0 & 17.5 & 16.8 & 17.0 & 14.8 & 11.7 & 6.1 & 4.6 & 3.8 & 646.1 & 17.5 \\
\hline World & 100 & 100 & 100 & 100 & 100 & 100 & 100 & 100 & 100 & 100 & 100 & 100 & 3697.5 & 100 \\
\hline
\end{tabular}

Source: Authors' calculations. 
Table 9: Global wealth distribution in 2000: country details based on PPP exchange rates

\begin{tabular}{|c|c|c|c|c|c|c|c|c|c|c|c|c|c|c|}
\hline & \multicolumn{5}{|c|}{ Quintiles } & \multicolumn{3}{|c|}{ Top } & \multirow{2}{*}{$\begin{array}{l}\text { Adult } \\
\text { population } \\
\text { (million) }\end{array}$} & \multirow{2}{*}{$\begin{array}{c}\text { Population } \\
\text { share } \\
\text { (\%) }\end{array}$} & \multirow{2}{*}{$\begin{array}{l}\text { Mean wealth } \\
\text { per adult } \\
\text { (PPP\$) }\end{array}$} & \multirow{2}{*}{$\begin{array}{l}\text { Wealth share } \\
(\%)\end{array}$} & \multirow{2}{*}{$\begin{array}{l}\text { Median wealth } \\
\text { per adult } \\
(\mathrm{PPP} \$)\end{array}$} & \multirow{2}{*}{ Gini } \\
\hline & Q1 & Q2 & Q3 & $\mathrm{Q} 4$ & Q5 & $10 \%$ & $5 \%$ & $1 \%$ & & & & & & \\
\hline USA & 3.7 & 6.8 & 7.1 & 9.8 & 27.5 & 19.4 & 23.3 & 36.8 & 202.9 & 5.5 & 201319 & 25.1 & 41682 & 0.801 \\
\hline Japan & 0.1 & 0.9 & 1.5 & 3.6 & 21.3 & 14.1 & 15.8 & 12.0 & 100.9 & 2.7 & 157146 & 9.7 & 93152 & 0.547 \\
\hline Germany & 3.5 & 1.0 & 1.6 & 2.6 & 8.9 & 7.0 & 8.9 & 3.9 & 64.8 & 1.8 & 115325 & 4.6 & 39709 & 0.667 \\
\hline UK & 0.4 & 1.2 & 1.7 & 2.0 & 6.7 & 5.9 & 5.8 & 6.4 & 43.9 & 1.2 & 172461 & 4.6 & 77439 & 0.697 \\
\hline Italy & 0.0 & 0.3 & 0.8 & 2.6 & 8.9 & 5.8 & 5.5 & 5.4 & 46.4 & 1.3 & 150327 & 4.3 & 80043 & 0.609 \\
\hline China & 17.3 & 42.3 & 73.8 & 64.9 & 29.4 & 5.3 & 2.3 & & 842.1 & 22.8 & 19056 & 9.9 & 10411 & 0.550 \\
\hline Spain & 0.1 & 0.6 & 0.8 & 1.0 & 6.1 & 3.6 & 3.5 & 1.4 & 32.2 & 0.9 & 117837 & 2.3 & 72483 & 0.570 \\
\hline France & 0.3 & 1.1 & 1.6 & 3.0 & 6.0 & 3.5 & 3.9 & 5.9 & 44.4 & 1.2 & 126360 & 3.4 & 36975 & 0.730 \\
\hline India & 40.3 & 44.9 & 32.9 & 25.9 & 10.3 & 2.5 & 1.2 & & 570.6 & 15.4 & 12021 & 4.2 & 4809 & 0.669 \\
\hline Canada & 0.6 & 0.7 & 0.5 & 1.0 & 3.3 & 2.3 & 2.2 & 2.3 & 22.8 & 0.6 & 120326 & 1.7 & 45850 & 0.688 \\
\hline Brazil & 8.0 & 5.9 & 4.8 & 5.3 & 4.3 & 1.8 & 1.6 & 1.4 & 104.2 & 2.8 & 27559 & 1.8 & 6046 & 0.784 \\
\hline Taiwan & 0.0 & 0.2 & 0.5 & 0.8 & 2.7 & 1.7 & 1.8 & 1.9 & 15.5 & 0.4 & 143405 & 1.4 & 62867 & 0.655 \\
\hline South Korea & 0.2 & 0.8 & 1.3 & 2.5 & 4.2 & 1.6 & 0.9 & 0.8 & 33.2 & 0.9 & 58314 & 1.2 & 33038 & 0.579 \\
\hline Australia & 0.4 & 0.3 & 0.3 & 0.2 & 2.4 & 1.6 & 1.7 & 1.3 & 13.7 & 0.4 & 126635 & 1.1 & 75027 & 0.622 \\
\hline Netherlands & 0.0 & 0.2 & 0.3 & 0.6 & 2.2 & 1.4 & 1.7 & 1.6 & 12.0 & 0.3 & 159910 & 1.2 & 71441 & 0.650 \\
\hline Mexico & 3.1 & 2.8 & 2.6 & 3.6 & 3.1 & 1.2 & 1.1 & 1.1 & 56.1 & 1.5 & 34879 & 1.2 & 9731 & 0.749 \\
\hline Argentina & 0.8 & 0.9 & 0.9 & 1.4 & 2.4 & 1.2 & 1.1 & 1.2 & 23.3 & 0.6 & 71115 & 1.0 & 20264 & 0.740 \\
\hline Russia & 6.7 & 6.3 & 5.7 & 6.9 & 3.5 & 1.0 & 0.8 & 0.6 & 107.5 & 2.9 & 20005 & 1.3 & 7438 & 0.699 \\
\hline Indonesia & 11.1 & 9.5 & 6.3 & 5.1 & 1.7 & 0.9 & 0.7 & 0.7 & 124.4 & 3.4 & 13642 & 1.0 & 3838 & 0.764 \\
\hline Turkey & 2.2 & 2.2 & 2.1 & 2.5 & 2.0 & 0.7 & 0.5 & 0.4 & 40.4 & 1.1 & 27657 & 0.7 & 9100 & 0.718 \\
\hline Thailand & 2.0 & 2.1 & 2.0 & 2.6 & 2.2 & 0.7 & 0.6 & 0.4 & 40.2 & 1.1 & 30344 & 0.7 & 10101 & 0.710 \\
\hline Pakistan & 5.0 & 5.3 & 4.4 & 2.4 & 1.2 & 0.4 & 0.3 & 0.2 & 68.0 & 1.8 & 12390 & 0.5 & 4643 & 0.698 \\
\hline Viet Nam & 3.0 & 3.0 & 2.6 & 2.4 & 1.0 & 0.3 & 0.2 & 0.1 & 44.0 & 1.2 & 14613 & 0.4 & 5684 & 0.682 \\
\hline Bangladesh & 6.2 & 5.7 & 3.6 & 1.9 & 0.5 & 0.1 & 0.1 & & 66.5 & 1.8 & 7734 & 0.3 & 3304 & 0.660 \\
\hline Nigeria & 11.6 & 1.6 & 0.5 & 0.2 & 0.0 & & & & 51.4 & 1.4 & 1423 & 0.0 & 434 & 0.736 \\
\hline World & 100 & 100 & 100 & 100 & 100 & 100 & 100 & 100 & 3697.5 & 100 & 44024 & 100 & 8635 & 0.802 \\
\hline
\end{tabular}

Note: Countries are listed according to the number of members of the global top wealth decile. Estimated figures in italics. Source: Authors' calculations. 
Table 10: Global wealth distribution under alternative assumptions

\begin{tabular}{|c|c|c|c|c|c|c|c|c|c|c|c|c|c|c|c|}
\hline & & \multirow{3}{*}{$\begin{array}{l}\text { Number of } \\
\text { countries }\end{array}$} & \multirow{3}{*}{$\begin{array}{c}\text { Adult } \\
\text { population } \\
\text { (million) }\end{array}$} & \multirow{3}{*}{$\begin{array}{c}\text { Share of adult } \\
\text { population } \\
(\%)\end{array}$} & \multirow{3}{*}{$\begin{array}{l}\text { Wealth per } \\
\text { adult } \\
(\$)\end{array}$} & \multirow{3}{*}{$\begin{array}{c}\text { Share of } \\
\text { wealth } \\
(\%)\end{array}$} & \multicolumn{8}{|c|}{ World wealth shares } & \multirow{3}{*}{ Gini } \\
\hline & & & & & & & \multicolumn{5}{|c|}{ Quintile } & \multicolumn{3}{|c|}{ Top } & \\
\hline & & & & & & & Q1 & Q2 & Q3 & Q4 & Q5 & $10 \%$ & $5 \%$ & $1 \%$ & \\
\hline & All countries, PPP valuations & 229 & 3697.5 & 100 & 44024 & 100 & 0.4 & 1.7 & 4.0 & 10.1 & 83.9 & 70.7 & 56.7 & 31.6 & 0.802 \\
\hline (2) & All countries, official exchange rates & 229 & 3697.5 & 100 & 33995 & 100 & 0.1 & 0.5 & 1.4 & 4.2 & 93.8 & 85.1 & 70.6 & 40.1 & 0.892 \\
\hline \multicolumn{16}{|c|}{ Excluding regional average imputations for: } \\
\hline & average wealth level & 148 & 3540.8 & 95.8 & 45047 & 98.0 & 0.4 & 1.7 & 4.0 & 10.1 & 83.8 & 70.7 & 56.5 & 31.6 & 0.801 \\
\hline & wealth distribution & 144 & 3596.8 & 97.3 & 44623 & 98.6 & 0.4 & 1.7 & 4.1 & 10.1 & 83.7 & 70.6 & 56.6 & 31.6 & 0.801 \\
\hline & average wealth level and distribution & 129 & 3491.1 & 94.4 & 45494 & 97.6 & 0.4 & 1.7 & 4.1 & 10.1 & 83.7 & 70.6 & 56.5 & 31.5 & 0.801 \\
\hline \multicolumn{16}{|c|}{ Countries with wealth distribution data: } \\
\hline (6) & using reported wealth distributions & 20 & 2171.1 & 58.7 & 56450 & 75.3 & 0.5 & 1.9 & 4.0 & 10.0 & 83.6 & 69.9 & 55.7 & 31.7 & 0.796 \\
\hline (7) & imputing from income distributions & 20 & 2171.1 & 58.7 & 56450 & 75.3 & 0.3 & 1.3 & 3.7 & 10.6 & 84.1 & 69.4 & 54.0 & 27.4 & 0.801 \\
\hline
\end{tabular}

Source: Authors' calculations. 
Appendix I: Household balance sheet (HBS) data: methods

There is considerable variation between countries in how household balance sheets are constructed, who puts them together, sectoral definition, and asset coverage. In some countries, for example Australia, the UK, and France the balance sheets, or at least their major elements, are compiled as part of the system of national accounts (SNA). Elsewhere, for example the USA, Canada, and Japan, they are assembled together with flow of funds (FOF) data. In other cases central banks or national statistical agencies issue HBS data independent of the SNA or FOF. The OECD publishes the financial balance sheet of the household sector for its member countries (OECD 2005). ${ }^{1}$ As reflected in our Table 1, however, fully comparable household balance sheets including non-financial assets are available for only a subset of OECD countries.

What is important is not who delivers the HBS data, but who and what are covered, and how the data are constructed. The objective is to estimate the balance sheet of the household sector as of a certain date- often but not always the year-end. This can be done by trying to measure the relevant stocks, or by updating previous stock figures by adding estimates of subsequent flows. Both stocks and flows can be measured by direct or indirect means (Aron et al. 2008). In the direct approach data are collected from household members through sample surveys, censuses or administrative records. In the indirect approach the values for the household sector by asset type are calculated as residuals from independent totals by deducting the estimated holdings of other sectors. Often the independent totals are counterpart data, for example the liabilities of the banking sector in the form of deposits. In most countries a mix of direct and indirect approaches is used.

In the USA, for example, most categories of financial assets and liabilities are calculated using the indirect approach (Board of Governors of the Federal Reserve System 2003). That is, amounts held or owed by the other sectors are subtracted from known totals and the remainders are assumed to be the amounts held by the household sector. For consumer credit no deductions are necessary. When microdata are available, assets and liability totals for the household sector are reviewed in light of that data and sometimes adjusted accordingly. The Survey of Consumer Finances (SCF), which is conducted every three years by the Federal Reserve Board, is used for this purpose. House values and equity in unincorporated business are estimated using the perpetual inventory method. Land values are updated based on an index of land prices.

In the UK, financial assets are measured mostly using the residual approach based on data from banks and other financial intermediaries. Ordinary shares are estimated with the help of a sample survey, the Share Registers Survey, whereas unlisted company shares are estimated using the estate multiplier method. Data on life assurance and pensions funds are obtained from returns made by insurance companies and pension funds. The value of fixed assets is derived using a number of sources. Some of the net capital stock estimates included in non-financial assets are calculated using the perpetual inventory method (Aron et al. 2008). Residential housing stock estimates are compiled using property tax records of local authorities, and farm land and buildings are estimated from data on farm sizes and prices from the Ministry of Agriculture, Fisheries and Food. 
As a final example, in Italy financial assets are also measured using the residual approach and are based on data from banks, credit institutions, insurance companies etc. (Brandolini et al. 2004). Debts comprise all short and long term liabilities and are estimated using the same approach. The stock of dwellings is based on a series provided by the Italian Statistics Office given at constant rather than market prices. The series is corrected to be expressed in market prices using a housing price series based on information assembled in a semi-annual survey of real estate agents. Benchmark values of the stock of dwellings and the share owned by households are obtained using census data. Apart from housing assets, only durables are included in fixed assets. The stock of durables is computed using the perpetual inventory method.

Non-financial coverage in the HBS data is not completely uniform. While the data for all countries considered here include owner-occupied housing there are variations in the coverage of other real estate and consumer durables, as reflected in Appendix IIB. It is difficult to devise a satisfactory estimation procedure for land or investment real estate, ${ }^{2}$ so these items have not been imputed. Since only four countries lack these items entirely, and eight countries, including the USA, have complete data, the impact would not be substantial, although the omissions will have some effect on our results, In contrast, it is reasonably easy to construct estimates of consumer durables, and since this improves the non-financial asset coverage for thirteen countries, these imputations were included. ${ }^{3}$

Appendix IIB also reveals differences in sectoral definition across countries. We aimed for a household sector which covered the assets and debts of households and unincorporated business. However, non-profit organizations (NPOs) are sometimes grouped with households. Data for the UK and USA allowed us to exclude NPOs. This correction is especially important for the USA, where NPOs account for about 6 per cent of the financial assets of the household sector (Board of Governors of the Federal Reserve System 2003). The USA appears to be something of an outlier in terms of the importance of NPOs.

\footnotetext{
1 Financial balance sheets for the household sector have also been published for eight countries in 'New Europe' by a financial group based in Italy. See UniCredit Group (2005). The countries covered are Bulgaria, Croatia, Czech Republic, Hungary, Poland, Romania, Slovakia, and Turkey. We were only able to obtain non-financial data for the Czech Republic, and so it is the only one of these countries for which complete balance sheet numbers are reported in this paper.

${ }^{2}$ While balance sheet figures for dwellings also capture the value of land on which they stand, other land is missing for Denmark, Germany, Italy, the Netherlands, and Singapore. Investment or commercial real estate is missing for the Netherlands, New Zealand, Portugal and Singapore, and for Italy (which covers all housing, whether owner occupied or not, but not other real estate). To the best of our knowledge, all real estate and land owned by households is included in the data in all other cases.

${ }^{3}$ Durables figures are available for Canada, the USA, Germany, Italy and South Africa. The mean ratio of durables to GDP in Canada and the USA was used to impute durables to Australia, New Zealand, and the UK. For European countries other than the UK, the mean ratio for Germany and Italy was used. Finally, the mean ratio for Canada, the USA, Germany, and Italy was used for imputations for Japan and Singapore.
} 
Appendix IIA: Balance sheet data sources

\begin{tabular}{|c|c|c|c|c|}
\hline Country & Financial data & Non-financial data & $\begin{array}{l}\text { Financial and Non-Financial Data } \\
\text { combined by... }\end{array}$ & Link to open-access official data \\
\hline Australia & $\begin{array}{c}\text { Australian Bureau of Statistics (2005). } 5204.0 \\
\text { Australian System of National Accounts Table } 51\end{array}$ & Same as for financial data & Australian Bureau of Statistics & wuw.abs.gov.au/ \\
\hline Austria & OECD (2005) & n.a. & n.a. & \\
\hline Belgium & OECD (2005) & n.a. & n.a. & \\
\hline Bulgaria & UniCredit Group (2005). & n.a. & n.a. & \\
\hline Canada & $\begin{array}{c}\text { Statistics Canada, National Balance Sheet } \\
\text { Accounts 2000; CanSim Matrix } 0751\end{array}$ & Same as for financial data & Statistics Canada & \\
\hline Croatia & UniCredit Group (2005). & n.a & n.a. & \\
\hline Czech Republic & $\begin{array}{c}\text { Czech Statistical Office. Sector Accounts Times } \\
\text { Series. Table ST01415, } 2006\end{array}$ & Same as for financial data & Czech Statistical Office & http://dw.czso.cz/ \\
\hline Denmark & $\begin{array}{c}\text { Statistics Denmark. National Accounts and } \\
\text { Balance of Payments, Annual National Accounts } \\
\text { ESA95, Balance Sheets for Financial Assets and } \\
\text { Liabilities Table NAT10 }\end{array}$ & $\begin{array}{l}\text { Statistics Denmark. National Accounts and } \\
\text { Balance of Payments, Annual National } \\
\text { Accounts ESA95, Fixed Capital Table Nat14 }\end{array}$ & Authors & www.statbank.dk/ \\
\hline Estonia & Eurostat Financial Balance Sheets & n.a. & n.a. & http://epp.eurostat.cec.eu.int/ \\
\hline Finland & $\begin{array}{l}\text { Statistics Finland. Financial Assets, Balance } \\
\text { Sheets. Financial Liabilities, Balance Sheets }\end{array}$ & $\begin{array}{c}\text { Housing stock from financial accounts } \\
\text { provided by Statistics Finland. }\end{array}$ & Authors & www.stat.fi \\
\hline France & $\begin{array}{c}\text { INSEE. Comptes Nationaux Annuels - Base } 2000 . \\
\text { Table } 4515\end{array}$ & Same as for financial data & INSEE & www.insee.fr/ \\
\hline Germany & $\begin{array}{c}\text { Deutsches Bundesbank (2004). Financial } \\
\text { Accounts for Germany } 1991 \text { to 2003. Special } \\
\text { Statistical Publication. Table XI p. } 86\end{array}$ & $\begin{array}{c}\text { Real assets data provided by Deutsches } \\
\text { Bundesbank. }\end{array}$ & Authors & \\
\hline Greece & Eurostat Financial Balance Sheets & n.a. & n.a. & http://epp.eurostat.cec.eu.int/ \\
\hline Hungary & OECD (2005). & n.a. & n.a. & \\
\hline Italy & Financial Accounts by the Bank of Italy. & Adjusted Italian Statistical Office data. & $\begin{array}{l}\text { Brandolini et al. (2004), Table 2, } \\
\text { p.18. }\end{array}$ & \\
\hline
\end{tabular}




\begin{tabular}{|c|c|c|c|c|}
\hline Japan & $\begin{array}{l}\text { Economic Planning Agency, Government of } \\
\text { Japan. Annual Report on National Accounts. } \\
\text { Table } 4\end{array}$ & Same as for financial data & $\begin{array}{l}\text { Economic Planning Agency, } \\
\text { Government of Japan }\end{array}$ & \\
\hline Korea & OECD (2005). & n.a. & n.a. & \\
\hline Latvia & Eurostat Financial Balance Sheets & n.a. & n.a. & http://epp.eurostat.cec.eu.int/ \\
\hline Lithuania & Eurostat Financial Balance Sheets & n.a. & n.a. & http://epp.eurostat.cec.eu.int/ \\
\hline Netherlands & van Els et al. (2005: Table 1 p.23) & $\begin{array}{l}\text { Statistics Netherlands. Sector Accounts: } \\
\text { Financial Balance Sheets Table 4b. }\end{array}$ & Authors & www.cbs.nl/ \\
\hline New Zealand & $\begin{array}{l}\text { Reserve Bank of New Zealand. Household } \\
\text { Financial Assets and Liabilities. }\end{array}$ & Same as for financial data & Reserve Bank of New Zealand & www.rbnz.govt.nz/ \\
\hline Poland & OECD (2005). & Yemtsov (2007). & Authors & \\
\hline Portugal & Financial Accounts by the Bank of Portugal. & $\begin{array}{l}\text { Housing stock estimates calculated based on } \\
\text { data from the Central Statistical Office and } \\
\text { the Bank of Portugal. }\end{array}$ & $\begin{array}{l}\text { Cardoso and da Cunha (2005: } \\
\text { Table A1.1 p.41) }\end{array}$ & \\
\hline Romania & UniCredit Group (2005). & n.a. & n.a. & \\
\hline Singapore & Singapore Department of Statistics (2003). & Same as for financial data & $\begin{array}{l}\text { Singapore Department of } \\
\text { Statistics }\end{array}$ & \\
\hline Slovakia & UniCredit Group (2005). & n.a. & n.a. & \\
\hline Slovenia & Eurostat Financial Balance Sheets & & n.a. & \\
\hline South Africa & Aron and Muellbauer (2004: Table 2 p.50) & Same as for financial data & Aron and Muellbauer (2004) & \\
\hline Spain & $\begin{array}{l}\text { Banco de Espana (2005). Financial Accounts of } \\
\text { the Spanish Economy. Table II.5.e. }\end{array}$ & $\begin{array}{l}\text { Banco de Espana. Summary indicators: } \\
\text { Household market indicators. }\end{array}$ & Authors & www.bde.es/ \\
\hline Sweden & OECD (2005). & n.a. & n.a. & \\
\hline Switzerland & $\begin{array}{l}\text { Swiss National Bank. Swiss Financial Accounts. } \\
\text { Table T11. }\end{array}$ & n.a. & n.a. & www.snb.ch \\
\hline Taiwan & $\begin{array}{l}\text { National Wealth Statistics. Statistical Tables. } \\
\text { Table } 7 \text { (quoted from Central Bank Flow of } \\
\text { Funds Statistics) }\end{array}$ & Same as for financial data & National Statistical Office & http://eng.stat.gov.tw/ \\
\hline Turkey & UniCredit Group (2005). & n.a. & n.a. & \\
\hline UK & $\begin{array}{l}\text { National Statistics Online. Financial Statistics } \\
\text { Time Series Data Table 12.1N. }\end{array}$ & $\begin{array}{l}\text { United Kingdom National Accounts. Blue } \\
\text { Book Time Series Data Table } 10.10 .\end{array}$ & Authors & www.statistics.gov.uk/ \\
\hline USA & $\begin{array}{l}\text { Federal Reserve Statistical Release. Flow of } \\
\text { Funds Accounts of the United States. Release } \\
\text { Z. I, June 9, 2005. Table B.100. }\end{array}$ & Same as for financial data & Federal Reserve & www.federalreserve.gov/ \\
\hline
\end{tabular}


Appendix IIB: Comparison of full household balance sheets

\begin{tabular}{|l|l|l|l|}
\hline Country & Sector definition & Non-housing real assets & $\begin{array}{l}\text { Consumer } \\
\text { durables }\end{array}$ \\
\hline Australia & households & yes & imputed \\
\hline Canada & households + NPOs & yes & yes \\
\hline Czech Republic & households & yes & imputed \\
\hline Denmark & households + NPOs & yes & imputed \\
\hline Finland & households & no & imputed \\
\hline France & households + NPOs & yes & imputed \\
\hline Germany & households & yes & yes \\
\hline Italy & households & yes (only durables) & yes \\
\hline Japan & households & yes & imputed \\
\hline Netherlands & households + NPOs & no & imputed \\
\hline New Zealand & households & yes (only land) & imputed \\
\hline Poland & households & no & imputed \\
\hline Portugal & households + NPOs & yes (only land) & imputed \\
\hline Singapore & households & no & imputed \\
\hline South Africa & households + NPOs & yes & yes \\
\hline Spain & households + NPOs & yes (only real estate) & imputed \\
\hline Taiwan & households & yes & yes \\
\hline UK & households (corrected for NPOs) & imputed \\
\hline USA (corrected for NPOs) & yes & yes \\
\hline
\end{tabular}

Note: NPOs are non-profit institutions serving households. 


\begin{tabular}{|c|c|c|}
\hline Australia & 2002 & Household Income, and Labour Dynamics; See Headey, et al (2005). \\
\hline Canada & 1999 & Survey of Financial Security; see Statistics Canada (2001). \\
\hline China & 2002 & China Academy of Social Science Survey; see Li and Zhao (2008). \\
\hline Denmark & 1996 & $\begin{array}{l}\text { Wealth tax records; see Statistics Denmark (1998) and Ohlson et al. (2006). Supplemented with } \\
\text { private communication with Statistics Denmark in } 2007 .\end{array}$ \\
\hline Finland & 1998 & Household Wealth Survey; see Statistics Finland (2000). \\
\hline France & 1994 & Estate tax returns; see Piketty et al (2004). \\
\hline Germany & 1998 & Einkommens und verbrauchstichprobe; see Ammermüller et al. (2005). \\
\hline India & 2002 & $\begin{array}{l}\text { All-India Debt and Investment Survey (NSS 59th round); see National Sample Survey } \\
\text { Organization (2005), and Subramanian and Jayaraj (2008). }\end{array}$ \\
\hline Indonesia & 1997 & Indonesia Family Life Survey (own calculations); www.rand.org/labor/FLS/IFLS/ \\
\hline Ireland & 1987 & The survey of Income Distribution, Poverty and Usage of State Services; see Nolan (1991). \\
\hline Italy & 2000 & Survey of Household Income and Wealth; see Brandolini et al. (2004). \\
\hline Japan & 1999 & National Survey of Family Income and Expenditure; see Japan Statistics Bureau (2005). \\
\hline Korea & 1988 & Korea Development Institute Survey; see Leipziger et al. (1992). \\
\hline Mexico & 2002 & Encuesta Nacional sobre Niveles de Vida de los Hogares; see Jäntti and Sierminska (2007). \\
\hline New Zealand & 2001 & Household Saving Survey; see Statistics New Zealand (2002). \\
\hline Norway & 2000 & Income and Property Distribution Survey; see Statistics Norway (2005). \\
\hline Spain & 2002 & Survey of Household Finances; see Banco de Espana (2005) and Alvaredo and Saez (2006). \\
\hline Sweden & 2002 & Wealth statistics based on registers of total population; see Statistics Sweden (2004). \\
\hline Switzerland & 1997 & Survey based on county wealth tax statistics; see Dell et al. (2005). \\
\hline UK & 2000 & Inland Revenue Statistics; see Inland Revenue Statistics (2005). \\
\hline USA & 2001 & Survey of Consumer Finances 2001; see Kennickel (2006). \\
\hline
\end{tabular}

Appendix IIC: Survey sources 
Appendix III: Wealth per capita from household balance sheet and survey data, 2000

\begin{tabular}{|c|c|c|c|c|c|}
\hline Country & $\begin{array}{l}\text { Wealth, }^{a} \\
\text { HBS }\end{array}$ & $\begin{array}{c}\text { Wealth, }{ }^{\text {a }} \text { survey } \\
\text { data }\end{array}$ & $\mathrm{GDP}^{\mathrm{b}}$ & $\begin{array}{c}\text { Personal } \\
\text { disposable income }\end{array}$ & Real consumption \\
\hline \multicolumn{6}{|c|}{ US\$ per capita at PPP exchange rates } \\
\hline Australia & 90906 & 101597 & 27193 & 15983 & 18913 \\
\hline Canada & 89252 & 72384 & 28731 & 17661 & 15994 \\
\hline China & & 11267 & 3844 & 1934 & 1870 \\
\hline Czech Republic & 32431 & & 14844 & 8205 & 10008 \\
\hline Denmark & 66191 & & 28539 & 12348 & 17951 \\
\hline Finland & 53154 & 38754 & 24416 & 11285 & 15197 \\
\hline France & 94557 & & 23614 & 14732 & 15672 \\
\hline Germany & 90768 & 55431 & 23917 & 15486 & 16603 \\
\hline India & & 6513 & 2684 & 1916 & 1406 \\
\hline Indonesia & & 7973 & 4035 & 2603 & 2614 \\
\hline Italy & 120897 & 74956 & 22876 & 15169 & 14195 \\
\hline Japan & 124858 & 91856 & 25924 & 15496 & 15975 \\
\hline Netherlands & 121165 & 43866 & 25759 & 12798 & 16159 \\
\hline New Zealand & 55823 & 61872 & 20008 & 12034 & 13534 \\
\hline Poland & 24654 & & 9661 & 7083 & 6493 \\
\hline Portugal & 53811 & & 17089 & 11700 & 10380 \\
\hline Singapore & 113631 & & 28644 & 14885 & 9965 \\
\hline South Africa & 16266 & & 8017 & 4691 & 5210 \\
\hline Spain & 93086 & 61218 & 19037 & 12544 & 13160 \\
\hline Taiwan & 100009 & & 19714 & 11471 & 12603 \\
\hline UK & 128959 & & 24252 & 17102 & 18238 \\
\hline USA & 143727 & 143857 & 35619 & 25480 & 24313 \\
\hline \multicolumn{6}{|c|}{ US\$ per capita at official exchange rates } \\
\hline Australia & 67990 & 75986 & 20338 & 11954 & 14145 \\
\hline Canada & 70916 & 57513 & 22828 & 14032 & 12708 \\
\hline China & & 2613 & 891 & 448 & 434 \\
\hline Czech Republic & 10797 & & 4942 & 2732 & 3332 \\
\hline Denmark & 70751 & & 30505 & 13198 & 19188 \\
\hline Finland & 50984 & 37171 & 23419 & 10824 & 14576 \\
\hline France & 85794 & & 21425 & 13367 & 14220 \\
\hline Germany & 86369 & 52744 & 22758 & 14735 & 15799 \\
\hline India & & 1112 & 458 & 327 & 240 \\
\hline Indonesia & & 1440 & 729 & 470 & 472 \\
\hline Italy & 98317 & 60957 & 18604 & 12336 & 11544 \\
\hline Japan & 180837 & 133038 & 37547 & 22443 & 23137 \\
\hline Netherlands & 109418 & 39613 & 23261 & 11557 & 14592 \\
\hline New Zealand & 37026 & 41038 & 13271 & 7982 & 8976 \\
\hline Poland & 10438 & & 4090 & 2999 & 2749 \\
\hline Portugal & 33421 & & 10614 & 7267 & 6447 \\
\hline Singapore & 90960 & & 22929 & 11915 & 7977 \\
\hline South Africa & 5977 & & 2946 & 1724 & 1914 \\
\hline Spain & 68693 & 45176 & 14048 & 9257 & 9711 \\
\hline Taiwan & 73654 & & 14519 & 8448 & 9282 \\
\hline UK & 126832 & & 23852 & 16820 & 17937 \\
\hline USA & 143727 & 143857 & 35619 & 25480 & 24313 \\
\hline
\end{tabular}


Notes and source: ${ }^{a}$ Source for HBS data: flow of funds data, national balance sheets and financial balance sheets augmented with estimates of housing assets. The original survey data are close to year 2000. Figures have been adjusted to year 2000 values using the real growth rate per capita. ${ }^{b}$ Source: Penn World Table 6.1. 'Source: The Economist Intelligence Unit. 


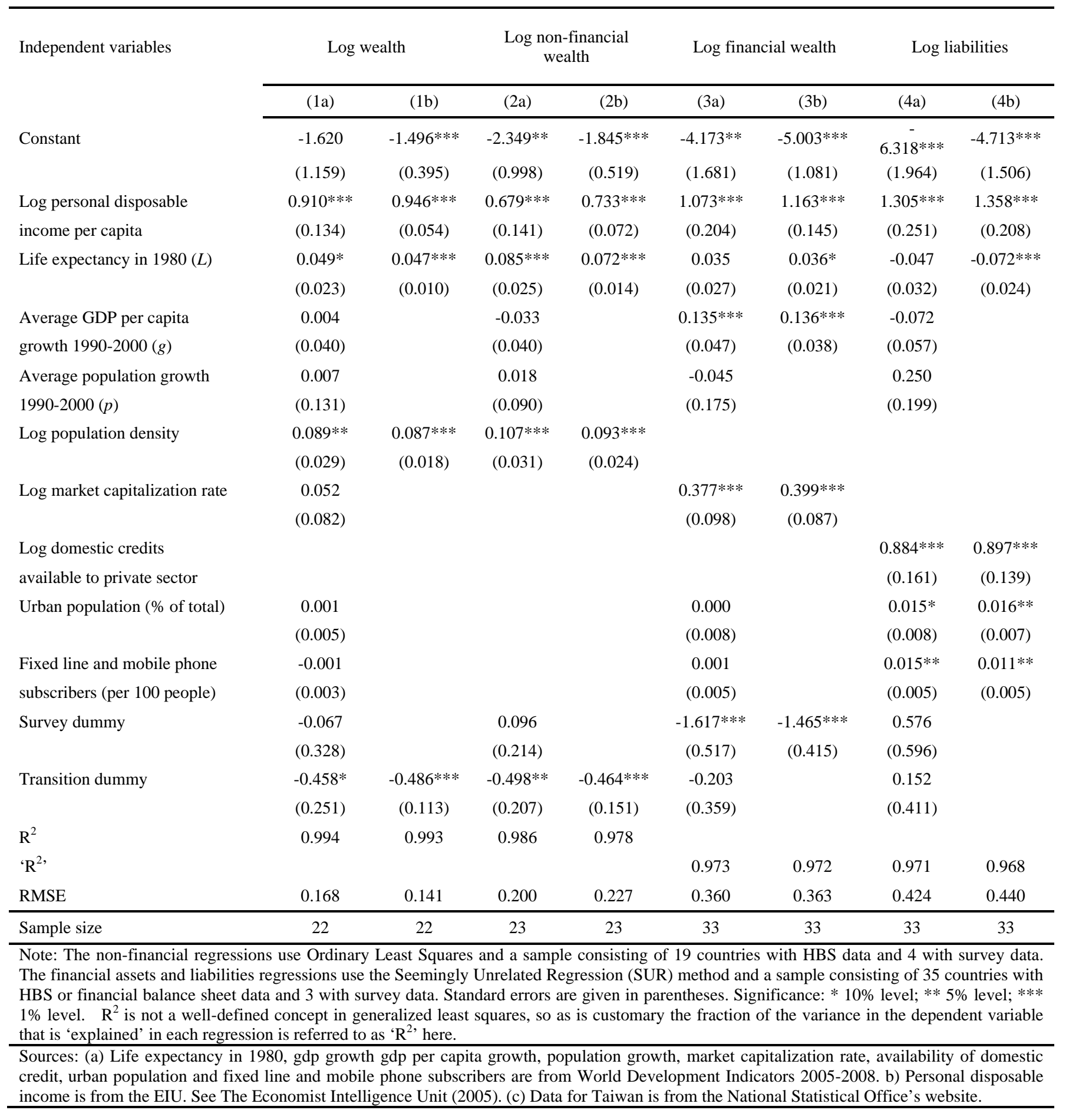


Appendix V: Population, wealth and GDP by country, 2000

\begin{tabular}{|c|c|c|c|c|c|c|c|c|c|c|c|c|c|c|c|}
\hline & \multirow[b]{2}{*}{$\begin{array}{l}\text { population } \\
\text { (000s) }\end{array}$} & \multirow[b]{2}{*}{$\begin{array}{l}\text { adults } \\
(000 s)\end{array}$} & \multirow[b]{2}{*}{$\begin{array}{c}\text { Share of } \\
\text { world } \\
\text { population } \\
(\%)\end{array}$} & \multirow[b]{2}{*}{$\begin{array}{l}\text { Share of } \\
\text { adult } \\
\text { population } \\
(\%)\end{array}$} & \multicolumn{5}{|c|}{ PPP\$ } & \multicolumn{5}{|c|}{ US\$ at official exchange rates } & \multirow[b]{2}{*}{$\begin{array}{c}\text { Wealth } \\
\text { Gini }\end{array}$} \\
\hline & & & & & $\begin{array}{c}\text { Wealth } \\
\text { per capita }\end{array}$ & $\begin{array}{c}\text { Wealth } \\
\text { per adult }\end{array}$ & $\begin{array}{c}\text { Share of } \\
\text { world } \\
\text { wealth } \\
(\%)\end{array}$ & $\begin{array}{c}\text { GDP per } \\
\text { capita }\end{array}$ & $\begin{array}{c}\text { Share of } \\
\text { world } \\
\text { GDP (\%) }\end{array}$ & $\begin{array}{c}\text { Wealth } \\
\text { per capita }\end{array}$ & $\begin{array}{l}\text { Wealth } \\
\text { per adult }\end{array}$ & $\begin{array}{c}\text { Share of } \\
\text { world } \\
\text { wealth } \\
(\%)\end{array}$ & $\begin{array}{c}\text { GDP per } \\
\text { capita }\end{array}$ & $\begin{array}{c}\text { Share of } \\
\text { world } \\
\text { GDP (\%) }\end{array}$ & \\
\hline \multicolumn{16}{|l|}{ North America } \\
\hline Canada & 30689 & 22764 & 0.50 & 0.62 & 89252 & 120326 & 1.68 & 28731 & 1.89 & 70916 & 95606 & 1.73 & 22828 & 2.18 & 0.688 \\
\hline USA & 284154 & 202865 & 4.67 & 5.49 & 143727 & 201319 & 25.10 & 35619 & 21.67 & 143727 & 201319 & 32.51 & 35619 & 31.47 & 0.801 \\
\hline \multicolumn{16}{|l|}{ Europe } \\
\hline Albania & 3062 & 1851 & 0.05 & 0.05 & 12444 & 20591 & 0.02 & 3658 & 0.02 & 3737 & 6184 & 0.01 & 1099 & 0.01 & 0.642 \\
\hline Austria & 8096 & 6271 & 0.13 & 0.17 & 76234 & 98418 & 0.38 & 24836 & 0.43 & 71408 & 92189 & 0.46 & 23264 & 0.59 & 0.646 \\
\hline Belarus & 10029 & 7335 & 0.17 & 0.20 & 21507 & 29408 & 0.13 & 8738 & 0.19 & 2503 & 3422 & 0.02 & 1017 & 0.03 & 0.628 \\
\hline Belgium & 10304 & 7896 & 0.17 & 0.21 & 120977 & 157868 & 0.77 & 25008 & 0.55 & 107950 & 140868 & 0.89 & 22315 & 0.72 & 0.662 \\
\hline Bulgaria & 7997 & 6192 & 0.13 & 0.17 & 18805 & 24286 & 0.09 & 6356 & 0.11 & 4340 & 5605 & 0.03 & 1467 & 0.04 & 0.652 \\
\hline Croatia & 4505 & 3430 & 0.07 & 0.09 & 18925 & 24859 & 0.05 & 9547 & 0.09 & 8620 & 11323 & 0.03 & 4349 & 0.06 & 0.654 \\
\hline Czech Rep. & 10267 & 7889 & 0.17 & 0.21 & 32431 & 42205 & 0.21 & 14844 & 0.33 & 10797 & 14051 & 0.09 & 4942 & 0.16 & 0.626 \\
\hline Denmark & 5340 & 4072 & 0.09 & 0.11 & 66191 & 86807 & 0.22 & 28539 & 0.33 & 70751 & 92787 & 0.30 & 30505 & 0.51 & 0.808 \\
\hline Estonia & 1367 & 1016 & 0.02 & 0.03 & 22859 & 30740 & 0.02 & 10873 & 0.03 & 7301 & 9819 & 0.01 & 3473 & 0.02 & 0.675 \\
\hline Finland & 5177 & 3905 & 0.09 & 0.11 & 53154 & 70461 & 0.17 & 24416 & 0.27 & 50984 & 67584 & 0.21 & 23419 & 0.38 & 0.615 \\
\hline France & 59278 & 44358 & 0.97 & 1.20 & 94557 & 126360 & 3.45 & 23614 & 3.00 & 85794 & 114650 & 4.05 & 21425 & 3.95 & 0.730 \\
\hline Germany & 82344 & 64810 & 1.35 & 1.75 & 90768 & 115325 & 4.59 & 23917 & 4.22 & 86369 & 109735 & 5.66 & 22758 & 5.83 & 0.667 \\
\hline Greece & 10975 & 8568 & 0.18 & 0.23 & 78161 & 100117 & 0.53 & 15558 & 0.37 & 53921 & 69068 & 0.47 & 10733 & 0.37 & 0.654 \\
\hline Hungary & 10226 & 7834 & 0.17 & 0.21 & 24751 & 32308 & 0.16 & 11063 & 0.24 & 10343 & 13500 & 0.08 & 4623 & 0.15 & 0.651 \\
\hline Iceland & 281 & 194 & 0.01 & 0.01 & 50784 & 73400 & 0.01 & 26929 & 0.02 & 57447 & 83030 & 0.01 & 30461 & 0.03 & 0.664 \\
\hline Ireland & 3801 & 2646 & 0.06 & 0.07 & 136680 & 196376 & 0.32 & 27197 & 0.22 & 126318 & 181489 & 0.38 & 25135 & 0.30 & 0.581 \\
\hline Italy & 57715 & 46416 & 0.95 & 1.26 & 120897 & 150327 & 4.29 & 22876 & 2.83 & 98317 & 122250 & 4.52 & 18604 & 3.34 & 0.609 \\
\hline Latvia & 2373 & 1770 & 0.04 & 0.05 & 15935 & 21369 & 0.02 & 8305 & 0.04 & 5780 & 7751 & 0.01 & 3013 & 0.02 & 0.670 \\
\hline Lithuania & 3500 & 2548 & 0.06 & 0.07 & 19703 & 27067 & 0.04 & 8397 & 0.06 & 7192 & 9879 & 0.02 & 3065 & 0.03 & 0.666 \\
\hline Luxembourg & 435 & 328 & 0.01 & 0.01 & 173137 & 229451 & 0.05 & 48968 & 0.05 & 151765 & 201127 & 0.05 & 42923 & 0.06 & 0.650 \\
\hline Macedonia & 2010 & 1398 & 0.03 & 0.04 & 14484 & 20819 & 0.02 & 5506 & 0.02 & 4613 & 6631 & 0.01 & 1754 & 0.01 & 0.661 \\
\hline Malta & 392 & 284 & 0.01 & 0.01 & 105038 & 145031 & 0.03 & 18256 & 0.02 & 56161 & 77544 & 0.02 & 9761 & 0.01 & 0.664 \\
\hline Moldova & 4275 & 2894 & 0.07 & 0.08 & 8704 & 12858 & 0.02 & 2212 & 0.02 & 1183 & 1748 & 0.00 & 301 & 0.00 & 0.691 \\
\hline
\end{tabular}




\begin{tabular}{|c|c|c|c|c|c|c|c|c|c|c|c|c|c|c|c|}
\hline Netherlands & 15898 & 12046 & 0.26 & 0.33 & 121165 & 159910 & 1.18 & 25759 & 0.88 & 109418 & 144406 & 1.38 & 23261 & 1.15 & 0.650 \\
\hline Norway & 4502 & 3337 & 0.07 & 0.09 & 90843 & 122553 & 0.25 & 32057 & 0.31 & 102074 & 137704 & 0.37 & 36021 & 0.50 & 0.633 \\
\hline Poland & 38649 & 27858 & 0.64 & 0.75 & 24654 & 34204 & 0.59 & 9661 & 0.80 & 10438 & 14481 & 0.32 & 4090 & 0.49 & 0.657 \\
\hline Portugal & 10225 & 7878 & 0.17 & 0.21 & 53811 & 69840 & 0.34 & 17089 & 0.37 & 33421 & 43377 & 0.27 & 10614 & 0.34 & 0.667 \\
\hline Romania & 22117 & 16431 & 0.36 & 0.44 & 13642 & 18362 & 0.19 & 5024 & 0.24 & 4436 & 5971 & 0.08 & 1634 & 0.11 & 0.651 \\
\hline Russia & 146560 & 107493 & 2.41 & 2.91 & 14672 & 20005 & 1.32 & 9996 & 3.14 & 2530 & 3449 & 0.30 & 1723 & 0.79 & 0.699 \\
\hline Slovakia & 5400 & 3900 & 0.09 & 0.11 & 27201 & 37662 & 0.09 & 12619 & 0.15 & 7693 & 10652 & 0.03 & 3569 & 0.06 & 0.629 \\
\hline Slovenia & 1967 & 1521 & 0.03 & 0.04 & 31127 & 40248 & 0.04 & 16983 & 0.07 & 16733 & 21636 & 0.03 & 9130 & 0.06 & 0.626 \\
\hline Spain & 40717 & 32165 & 0.67 & 0.87 & 93086 & 117837 & 2.33 & 19037 & 1.66 & 68693 & 86958 & 2.23 & 14048 & 1.78 & 0.570 \\
\hline Sweden & 8877 & 6735 & 0.15 & 0.18 & 73570 & 96961 & 0.40 & 24628 & 0.47 & 77085 & 101594 & 0.55 & 25805 & 0.71 & 0.742 \\
\hline Switzerland & 7167 & 5497 & 0.12 & 0.15 & 140346 & 182992 & 0.62 & 28209 & 0.43 & 166208 & 216712 & 0.95 & 33407 & 0.74 & 0.803 \\
\hline Ukraine & 49116 & 36573 & 0.81 & 0.99 & 14010 & 18815 & 0.42 & 5147 & 0.54 & 1751 & 2352 & 0.07 & 643 & 0.10 & 0.667 \\
\hline UK & 58670 & 43871 & 0.96 & 1.19 & 128959 & 172461 & 4.65 & 24252 & 3.05 & 126832 & 169617 & 5.92 & 23852 & 4.35 & 0.697 \\
\hline \multicolumn{16}{|c|}{ Rich Asia Pacific } \\
\hline Australia & 19071 & 13690 & 0.31 & 0.37 & 90906 & 126635 & 1.07 & 27193 & 1.11 & 67990 & 94712 & 1.03 & 20338 & 1.21 & 0.622 \\
\hline Hong Kong & 6637 & 5085 & 0.11 & 0.14 & 175191 & 228675 & 0.72 & 27893 & 0.40 & 150206 & 196062 & 0.79 & 23915 & 0.49 & 0.740 \\
\hline Israel & 6084 & 3836 & 0.10 & 0.10 & 72009 & 114210 & 0.27 & 19148 & 0.25 & 66581 & 105601 & 0.32 & 17705 & 0.34 & 0.677 \\
\hline Japan & 127034 & 100933 & 2.09 & 2.73 & 124858 & 157146 & 9.75 & 25924 & 7.05 & 180837 & 227600 & 18.28 & 37547 & 14.83 & 0.547 \\
\hline Korea & 46779 & 33242 & 0.77 & 0.90 & 41439 & 58314 & 1.19 & 14937 & 1.50 & 26832 & 37758 & 1.00 & 9671 & 1.41 & 0.579 \\
\hline Macao & 444 & 310 & 0.01 & 0.01 & 86672 & 124280 & 0.02 & 23118 & 0.02 & 53131 & 76186 & 0.02 & 14172 & 0.02 & 0.580 \\
\hline New Zealand & 3818 & 2678 & 0.06 & 0.07 & 55823 & 79585 & 0.13 & 20008 & 0.16 & 37026 & 52786 & 0.11 & 13271 & 0.16 & 0.651 \\
\hline Singapore & 4017 & 2890 & 0.07 & 0.08 & 113632 & 157942 & 0.28 & 28644 & 0.25 & 90960 & 126429 & 0.29 & 22929 & 0.29 & 0.689 \\
\hline Taiwan & 22191 & 15476 & 0.37 & 0.42 & 100009 & 143405 & 1.36 & 19714 & 0.94 & 73654 & 105613 & 1.30 & 14519 & 1.00 & 0.655 \\
\hline \multicolumn{16}{|c|}{ China and India } \\
\hline China & 1251788 & 842063 & 20.57 & 22.77 & 12819 & 19056 & 9.86 & 3844 & 10.30 & 2973 & 4420 & 2.96 & 891 & 3.47 & 0.550 \\
\hline India & 1021084 & 570595 & 16.78 & 15.43 & 6718 & 12021 & 4.22 & 2684 & 5.87 & 1146 & 2052 & 0.93 & 458 & 1.45 & 0.669 \\
\hline \multicolumn{16}{|c|}{ Other Asia Pacific } \\
\hline Armenia & 3082 & 1986 & 0.05 & 0.05 & 14921 & 23155 & 0.03 & 3068 & 0.02 & 2420 & 3755 & 0.01 & 498 & 0.01 & 0.684 \\
\hline Azerbaijan & 8143 & 4816 & 0.13 & 0.13 & 9109 & 15402 & 0.05 & 3555 & 0.06 & 1677 & 2836 & 0.01 & 654 & 0.02 & 0.678 \\
\hline Bangladesh & 128916 & 66483 & 2.12 & 1.80 & 3988 & 7734 & 0.32 & 1772 & 0.49 & 780 & 1513 & 0.08 & 347 & 0.14 & 0.660 \\
\hline Cambodia & 12744 & 5847 & 0.21 & 0.16 & 2089 & 4553 & 0.02 & 1859 & 0.05 & 322 & 703 & 0.00 & 287 & 0.01 & 0.714 \\
\hline Fiji & 811 & 453 & 0.01 & 0.01 & 12110 & 21669 & 0.01 & 4950 & 0.01 & 4988 & 8924 & 0.00 & 2039 & 0.01 & 0.709 \\
\hline Georgia & 4720 & 3326 & 0.08 & 0.09 & 30286 & 42976 & 0.09 & 5315 & 0.05 & 3372 & 4784 & 0.01 & 592 & 0.01 & 0.725 \\
\hline Indonesia & 209174 & 124446 & 3.44 & 3.37 & 8116 & 13642 & 1.04 & 4035 & 1.81 & 1466 & 2464 & 0.24 & 729 & 0.47 & 0.764 \\
\hline
\end{tabular}




\begin{tabular}{|c|c|c|c|c|c|c|c|c|c|c|c|c|c|c|c|}
\hline Iran & 66365 & 34053 & 1.09 & 0.92 & 12051 & 23486 & 0.49 & 7202 & 1.02 & 7971 & 15534 & 0.42 & 4764 & 0.98 & 0.707 \\
\hline Jordan & 4972 & 2474 & 0.08 & 0.07 & 12020 & 24154 & 0.04 & 4282 & 0.05 & 4747 & 9539 & 0.02 & 1691 & 0.03 & 0.678 \\
\hline Kazakhstan & 15033 & 9507 & 0.25 & 0.26 & 13256 & 20961 & 0.12 & 8331 & 0.27 & 1967 & 3110 & 0.02 & 1236 & 0.06 & 0.655 \\
\hline Kyrgyzstan & 4952 & 2706 & 0.08 & 0.07 & 7984 & 14612 & 0.02 & 3205 & 0.03 & 668 & 1222 & 0.00 & 268 & 0.00 & 0.680 \\
\hline Lebanon & 3398 & 2024 & 0.06 & 0.06 & 27438 & 46070 & 0.06 & 6089 & 0.04 & 17148 & 28793 & 0.05 & 3806 & 0.04 & 0.762 \\
\hline Malaysia & 22997 & 12944 & 0.38 & 0.35 & 23239 & 41288 & 0.33 & 9422 & 0.46 & 9479 & 16841 & 0.17 & 3843 & 0.28 & 0.733 \\
\hline Pakistan & 142648 & 67968 & 2.34 & 1.84 & 5904 & 12390 & 0.52 & 2158 & 0.66 & 1176 & 2469 & 0.13 & 430 & 0.19 & 0.698 \\
\hline Papua N. Guinea & 5299 & 2544 & 0.09 & 0.07 & 2477 & 5159 & 0.01 & 2326 & 0.03 & 687 & 1432 & 0.00 & 645 & 0.01 & 0.738 \\
\hline Philippines & 75766 & 39206 & 1.25 & 1.06 & 14780 & 28562 & 0.69 & 4065 & 0.66 & 3682 & 7116 & 0.22 & 1013 & 0.24 & 0.717 \\
\hline Saudi Arabia & 21484 & 10992 & 0.35 & 0.30 & 14355 & 28056 & 0.19 & 12374 & 0.57 & 10175 & 19887 & 0.17 & 8771 & 0.59 & 0.737 \\
\hline Sri Lanka & 19848 & 12689 & 0.33 & 0.34 & 21634 & 33839 & 0.26 & 3841 & 0.16 & 4745 & 7422 & 0.08 & 842 & 0.05 & 0.665 \\
\hline Syria & 16813 & 7920 & 0.28 & 0.21 & 7337 & 15576 & 0.08 & 4338 & 0.16 & 8386 & 17803 & 0.11 & 4958 & 0.26 & 0.704 \\
\hline Tajikistan & 6159 & 2866 & 0.10 & 0.08 & 4106 & 8823 & 0.02 & 1380 & 0.02 & 415 & 892 & 0.00 & 140 & 0.00 & 0.664 \\
\hline Thailand & 61438 & 40160 & 1.01 & 1.09 & 19835 & 30344 & 0.75 & 6715 & 0.88 & 5875 & 8987 & 0.29 & 1989 & 0.38 & 0.710 \\
\hline Turkey & 68234 & 40391 & 1.12 & 1.09 & 16372 & 27657 & 0.69 & 7414 & 1.08 & 6605 & 11158 & 0.36 & 2991 & 0.64 & 0.718 \\
\hline Viet Nam & 78671 & 44025 & 1.29 & 1.19 & 8178 & 14613 & 0.40 & 2012 & 0.34 & 1614 & 2884 & 0.10 & 397 & 0.10 & 0.682 \\
\hline Yemen & 17937 & 7209 & 0.30 & 0.20 & 892 & 2219 & 0.01 & 1293 & 0.05 & 336 & 836 & 0.01 & 487 & 0.03 & 0.613 \\
\hline \multicolumn{16}{|c|}{ Latin America and Caribbean } \\
\hline Antigua and Barbuda & 77 & 52 & 0.00 & 0.00 & 30683 & 45291 & 0.00 & 18007 & 0.00 & 17274 & 25497 & 0.00 & 10137 & 0.00 & 0.747 \\
\hline Argentina & 36896 & 23307 & 0.61 & 0.63 & 44923 & 71115 & 1.02 & 11729 & 0.93 & 29664 & 46959 & 0.87 & 7745 & 0.89 & 0.740 \\
\hline Barbados & 266 & 190 & 0.00 & 0.01 & 107153 & 150298 & 0.02 & 17526 & 0.01 & 60006 & 84167 & 0.01 & 9815 & 0.01 & 0.706 \\
\hline Belize & 242 & 119 & 0.00 & 0.00 & 20327 & 41213 & 0.00 & 7170 & 0.00 & 9655 & 19576 & 0.00 & 3406 & 0.00 & 0.763 \\
\hline Bolivia & 8317 & 4171 & 0.14 & 0.11 & 4110 & 8196 & 0.02 & 2934 & 0.05 & 1396 & 2784 & 0.01 & 996 & 0.03 & 0.762 \\
\hline Brazil & 173858 & 104213 & 2.86 & 2.82 & 16519 & 27559 & 1.77 & 7745 & 2.88 & 7492 & 12498 & 1.04 & 3512 & 1.90 & 0.784 \\
\hline Chile & 15412 & 9809 & 0.25 & 0.27 & 45329 & 71221 & 0.43 & 10389 & 0.34 & 20222 & 31773 & 0.25 & 4635 & 0.22 & 0.777 \\
\hline Colombia & 42120 & 24197 & 0.69 & 0.65 & 18000 & 31334 & 0.47 & 5796 & 0.52 & 5957 & 10370 & 0.20 & 1918 & 0.25 & 0.765 \\
\hline Costa Rica & 3929 & 2284 & 0.07 & 0.06 & 26554 & 45681 & 0.06 & 5873 & 0.05 & 18825 & 32386 & 0.06 & 4164 & 0.05 & 0.732 \\
\hline Dominica & 78 & 46 & 0.00 & 0.00 & 23372 & 39513 & 0.00 & 8284 & 0.00 & 10474 & 17708 & 0.00 & 3712 & 0.00 & 0.763 \\
\hline Dominican Rep. & 8265 & 4462 & 0.14 & 0.12 & 14223 & 26344 & 0.07 & 5654 & 0.10 & 5918 & 10961 & 0.04 & 2352 & 0.06 & 0.723 \\
\hline Ecuador & 12306 & 6770 & 0.20 & 0.18 & 9411 & 17108 & 0.07 & 3720 & 0.10 & 2717 & 4940 & 0.03 & 1074 & 0.04 & 0.760 \\
\hline El Salvador & 6280 & 3389 & 0.10 & 0.09 & 12150 & 22517 & 0.05 & 4622 & 0.06 & 5551 & 10288 & 0.03 & 2112 & 0.04 & 0.746 \\
\hline Guatemala & 11166 & 4986 & 0.18 & 0.14 & 8911 & 19957 & 0.06 & 4335 & 0.10 & 3444 & 7712 & 0.03 & 1675 & 0.06 & 0.779 \\
\hline Guyana & 744 & 433 & 0.01 & 0.01 & 6995 & 12021 & 0.00 & 4072 & 0.01 & 1645 & 2828 & 0.00 & 958 & 0.00 & 0.707 \\
\hline Haiti & 7939 & 3745 & 0.13 & 0.10 & 3800 & 8056 & 0.02 & 1798 & 0.03 & 984 & 2086 & 0.01 & 466 & 0.01 & 0.755 \\
\hline
\end{tabular}




\begin{tabular}{|c|c|c|c|c|c|c|c|c|c|c|c|c|c|c|c|}
\hline Honduras & 6424 & 3025 & 0.11 & 0.08 & 5572 & 11833 & 0.02 & 2164 & 0.03 & 2377 & 5048 & 0.01 & 923 & 0.02 & 0.743 \\
\hline Jamaica & 2585 & 1478 & 0.04 & 0.04 & 16457 & 28775 & 0.03 & 3464 & 0.02 & 13528 & 23653 & 0.03 & 2848 & 0.02 & 0.686 \\
\hline Mexico & 100088 & 56132 & 1.65 & 1.52 & 19561 & 34879 & 1.20 & 9711 & 2.08 & 11895 & 21210 & 0.95 & 5905 & 1.84 & 0.749 \\
\hline Nicaragua & 4959 & 2279 & 0.08 & 0.06 & 5781 & 12577 & 0.02 & 1947 & 0.02 & 1404 & 3054 & 0.01 & 473 & 0.01 & 0.755 \\
\hline Panama & 2950 & 1731 & 0.05 & 0.05 & 25776 & 43935 & 0.05 & 6650 & 0.04 & 13404 & 22846 & 0.03 & 3458 & 0.03 & 0.766 \\
\hline Paraguay & 5470 & 2703 & 0.09 & 0.07 & 16335 & 33058 & 0.06 & 4801 & 0.06 & 4654 & 9418 & 0.02 & 1368 & 0.02 & 0.766 \\
\hline Peru & 25952 & 14348 & 0.43 & 0.39 & 10245 & 18531 & 0.16 & 4799 & 0.27 & 4462 & 8071 & 0.09 & 2090 & 0.17 & 0.738 \\
\hline Puerto Rico & 3835 & 2609 & 0.06 & 0.07 & 85219 & 125269 & 0.20 & 22242 & 0.18 & 61293 & 90098 & 0.19 & 15998 & 0.19 & 0.753 \\
\hline St Kitts and Nevis & 40 & 24 & 0.00 & 0.00 & 18919 & 31985 & 0.00 & 14627 & 0.00 & 9880 & 16703 & 0.00 & 7639 & 0.00 & 0.763 \\
\hline St Lucia & 154 & 89 & 0.00 & 0.00 & 23519 & 40644 & 0.00 & 6823 & 0.00 & 15593 & 26945 & 0.00 & 4523 & 0.00 & 0.763 \\
\hline St Vincent-Grenadines & 116 & 64 & 0.00 & 0.00 & 17556 & 31620 & 0.00 & 7847 & 0.00 & 6502 & 11711 & 0.00 & 2906 & 0.00 & 0.741 \\
\hline Trinidad and Tobago & 1285 & 817 & 0.02 & 0.02 & 59612 & 93754 & 0.05 & 13721 & 0.04 & 26116 & 41075 & 0.03 & 6011 & 0.02 & 0.689 \\
\hline Uruguay & 3342 & 2259 & 0.06 & 0.06 & 26344 & 38973 & 0.05 & 10285 & 0.07 & 15393 & 22773 & 0.04 & 6009 & 0.06 & 0.708 \\
\hline Venezuela & 24418 & 13707 & 0.40 & 0.37 & 17155 & 30560 & 0.26 & 7232 & 0.38 & 11845 & 21100 & 0.23 & 4994 & 0.38 & 0.712 \\
\hline \multicolumn{16}{|l|}{ Africa } \\
\hline$\overline{\text { Algeria }}$ & 30463 & 16353 & 0.50 & 0.44 & 7308 & 13613 & 0.14 & 6107 & 0.40 & 2098 & 3909 & 0.05 & 1754 & 0.17 & 0.670 \\
\hline Benin & 7197 & 3112 & 0.12 & 0.08 & 2216 & 5124 & 0.01 & 1225 & 0.02 & 624 & 1444 & 0.00 & 345 & 0.01 & 0.713 \\
\hline Botswana & 1754 & 851 & 0.03 & 0.02 & 14266 & 29407 & 0.02 & 7703 & 0.03 & 5545 & 11429 & 0.01 & 2994 & 0.02 & 0.751 \\
\hline Burkina Faso & 11292 & 4591 & 0.19 & 0.12 & 1479 & 3637 & 0.01 & 986 & 0.02 & 292 & 718 & 0.00 & 195 & 0.01 & 0.728 \\
\hline Burundi & 6486 & 2607 & 0.11 & 0.07 & 1437 & 3575 & 0.01 & 619 & 0.01 & 251 & 624 & 0.00 & 108 & 0.00 & 0.699 \\
\hline Cameroon & 14856 & 6819 & 0.24 & 0.18 & 3400 & 7407 & 0.03 & 2301 & 0.07 & 814 & 1773 & 0.01 & 551 & 0.03 & 0.711 \\
\hline Cape Verde & 451 & 202 & 0.01 & 0.01 & 11001 & 24589 & 0.00 & 4299 & 0.00 & 3239 & 7240 & 0.00 & 1266 & 0.00 & 0.688 \\
\hline Central African Rep. & 3777 & 1738 & 0.06 & 0.05 & 1276 & 2774 & 0.00 & 1148 & 0.01 & 280 & 609 & 0.00 & 252 & 0.00 & 0.782 \\
\hline Chad & 8216 & 3501 & 0.14 & 0.10 & 1337 & 3138 & 0.01 & 959 & 0.02 & 255 & 598 & 0.00 & 183 & 0.01 & 0.681 \\
\hline Comoros & 699 & 315 & 0.01 & 0.01 & 3474 & 7702 & 0.00 & 1823 & 0.00 & 689 & 1529 & 0.00 & 362 & 0.00 & 0.711 \\
\hline Congo Dem. Rep. & 50052 & 21050 & 0.82 & 0.57 & 1288 & 3062 & 0.04 & 669 & 0.07 & 166 & 394 & 0.01 & 86 & 0.01 & 0.711 \\
\hline Congo Rep. & 3438 & 1468 & 0.06 & 0.04 & 2570 & 6021 & 0.01 & 2533 & 0.02 & 1037 & 2428 & 0.00 & 1022 & 0.01 & 0.711 \\
\hline Côte d'Ivoire & 16735 & 7529 & 0.28 & 0.20 & 3936 & 8749 & 0.04 & 2028 & 0.07 & 1137 & 2527 & 0.02 & 586 & 0.03 & 0.712 \\
\hline Egypt & 67285 & 35550 & 1.11 & 0.96 & 10146 & 19203 & 0.42 & 4406 & 0.64 & 3507 & 6637 & 0.19 & 1523 & 0.32 & 0.689 \\
\hline Equatorial Guinea & 449 & 206 & 0.01 & 0.01 & 3026 & 6584 & 0.00 & 10302 & 0.01 & 863 & 1877 & 0.00 & 2938 & 0.00 & 0.688 \\
\hline Ethiopia & 68525 & 30020 & 1.13 & 0.81 & 1053 & 2404 & 0.04 & 720 & 0.11 & 144 & 328 & 0.01 & 98 & 0.02 & 0.652 \\
\hline Gabon & 1272 & 603 & 0.02 & 0.02 & 6315 & 13318 & 0.01 & 7780 & 0.02 & 3254 & 6861 & 0.00 & 4008 & 0.02 & 0.784 \\
\hline Gambia & 1316 & 643 & 0.02 & 0.02 & 1650 & 3374 & 0.00 & 1329 & 0.00 & 401 & 821 & 0.00 & 323 & 0.00 & 0.723 \\
\hline Ghana & 19867 & 9418 & 0.33 & 0.26 & 3776 & 7965 & 0.05 & 1376 & 0.06 & 709 & 1495 & 0.01 & 258 & 0.02 & 0.692 \\
\hline
\end{tabular}




\begin{tabular}{|c|c|c|c|c|c|c|c|c|c|c|c|c|c|c|c|}
\hline Guinea & 8434 & 3876 & 0.14 & 0.11 & 2626 & 5715 & 0.01 & 2961 & 0.05 & 361 & 785 & 0.00 & 407 & 0.01 & 0.693 \\
\hline Guinea-Bissau & 1366 & 588 & 0.02 & 0.02 & 603 & 1400 & 0.00 & 738 & 0.00 & 147 & 342 & 0.00 & 180 & 0.00 & 0.710 \\
\hline Kenya & 30689 & 13409 & 0.50 & 0.36 & 4203 & 9619 & 0.08 & 1316 & 0.09 & 1106 & 2532 & 0.03 & 346 & 0.03 & 0.699 \\
\hline Lesotho & 1788 & 825 & 0.03 & 0.02 & 2606 & 5649 & 0.00 & 1492 & 0.01 & 770 & 1669 & 0.00 & 441 & 0.00 & 0.767 \\
\hline Madagascar & 16195 & 7260 & 0.27 & 0.20 & 1397 & 3116 & 0.01 & 877 & 0.03 & 398 & 887 & 0.01 & 249 & 0.01 & 0.722 \\
\hline Malawi & 11512 & 4970 & 0.19 & 0.13 & 1537 & 3561 & 0.01 & 808 & 0.02 & 313 & 725 & 0.00 & 165 & 0.01 & 0.736 \\
\hline Mali & 11647 & 4691 & 0.19 & 0.13 & 874 & 2170 & 0.01 & 996 & 0.03 & 186 & 462 & 0.00 & 212 & 0.01 & 0.750 \\
\hline Mauritania & 2645 & 1225 & 0.04 & 0.03 & 3370 & 7279 & 0.01 & 1729 & 0.01 & 796 & 1720 & 0.00 & 409 & 0.00 & 0.686 \\
\hline Mauritius & 1186 & 779 & 0.02 & 0.02 & 70234 & 106929 & 0.05 & 14406 & 0.04 & 18007 & 27415 & 0.02 & 3693 & 0.01 & 0.661 \\
\hline Morocco & 29231 & 16167 & 0.48 & 0.44 & 10805 & 19535 & 0.19 & 4299 & 0.27 & 2929 & 5295 & 0.07 & 1165 & 0.11 & 0.690 \\
\hline Mozambique & 17911 & 8088 & 0.29 & 0.22 & 1224 & 2711 & 0.01 & 1113 & 0.04 & 237 & 524 & 0.00 & 215 & 0.01 & 0.689 \\
\hline Namibia & 1894 & 874 & 0.03 & 0.02 & 7384 & 15998 & 0.01 & 6058 & 0.03 & 2196 & 4759 & 0.00 & 1802 & 0.01 & 0.847 \\
\hline Niger & 11782 & 4758 & 0.19 & 0.13 & 849 & 2101 & 0.01 & 902 & 0.02 & 159 & 393 & 0.00 & 169 & 0.01 & 0.729 \\
\hline Nigeria & 117608 & 51431 & 1.93 & 1.39 & 622 & 1423 & 0.05 & 826 & 0.21 & 244 & 559 & 0.02 & 325 & 0.12 & 0.736 \\
\hline Rwanda & 8025 & 3250 & 0.13 & 0.09 & 1686 & 4163 & 0.01 & 976 & 0.02 & 364 & 900 & 0.00 & 211 & 0.01 & 0.714 \\
\hline Senegal & 10343 & 4547 & 0.17 & 0.12 & 2795 & 6357 & 0.02 & 1681 & 0.04 & 762 & 1734 & 0.01 & 459 & 0.02 & 0.697 \\
\hline Seychelles & 77 & 43 & 0.00 & 0.00 & 28111 & 50598 & 0.00 & 11644 & 0.00 & 18252 & 32853 & 0.00 & 7561 & 0.00 & 0.760 \\
\hline Sierra Leone & 4509 & 2136 & 0.07 & 0.06 & 738 & 1558 & 0.00 & 734 & 0.01 & 128 & 269 & 0.00 & 127 & 0.00 & 0.687 \\
\hline South Africa & 45610 & 25480 & 0.75 & 0.69 & 16266 & 29118 & 0.46 & 8017 & 0.78 & 5977 & 10699 & 0.22 & 2946 & 0.42 & 0.763 \\
\hline Swaziland & 1023 & 444 & 0.02 & 0.01 & 6789 & 15636 & 0.00 & 5047 & 0.01 & 1732 & 3988 & 0.00 & 1287 & 0.00 & 0.780 \\
\hline Tanzania & 34763 & 15569 & 0.57 & 0.42 & 932 & 2080 & 0.02 & 490 & 0.04 & 509 & 1137 & 0.01 & 268 & 0.03 & 0.676 \\
\hline Togo & 5364 & 2379 & 0.09 & 0.06 & 2314 & 5219 & 0.01 & 926 & 0.01 & 674 & 1519 & 0.00 & 270 & 0.00 & 0.711 \\
\hline Tunisia & 9563 & 5638 & 0.16 & 0.15 & 21716 & 36836 & 0.13 & 7130 & 0.15 & 6179 & 10481 & 0.05 & 2029 & 0.06 & 0.693 \\
\hline Uganda & 24309 & 9370 & 0.40 & 0.25 & 2207 & 5726 & 0.03 & 1030 & 0.05 & 551 & 1429 & 0.01 & 257 & 0.02 & 0.723 \\
\hline Zambia & 10702 & 4517 & 0.18 & 0.12 & 1550 & 3672 & 0.01 & 841 & 0.02 & 577 & 1366 & 0.01 & 313 & 0.01 & 0.766 \\
\hline Zimbabwe & 12595 & 5631 & 0.21 & 0.15 & 7695 & 17212 & 0.06 & 2607 & 0.07 & 1642 & 3674 & 0.02 & 556 & 0.02 & 0.845 \\
\hline Other countries & 294154 & 156876 & 4.83 & 4.24 & & & 1.98 & & 2.09 & & & 1.39 & & 1.47 & \\
\hline World & 6085576 & 3697511 & 100.00 & 100.00 & 26738 & 44024 & 100.00 & 7675 & 100.00 & 20646 & 33981 & 100.00 & 5285 & 100.00 & 0.804 \\
\hline
\end{tabular}

